\title{
Advanced Chemical Reactor Technologies for Biodiesel Production from Vegetable Oils - A Review
}

\author{
Luqman Buchori, I. Istadi*, P. Purwanto \\ Department of Chemical Engineering, Faculty of Engineering, Diponegoro University \\ Jl. Prof. Soedarto, SH, Kampus Undip Tembalang, Semarang 50275, Indonesia
}

Received: 17th May 2016; Revised: 20 th September 2016; Accepted: 20 th September 2016

\begin{abstract}
Biodiesel is an alternative biofuel that can replace diesel oil without requiring modifications to the engine and advantageously produces cleaner emissions. Biodiesel can be produced through transesterification process between oil or fat and alcohol to form esters and glycerol. The transesterification can be carried out with or without a catalyst. The catalyzed production of biodiesel can be performed by using homogeneous, heterogeneous and enzyme. Meanwhile, non-catalytic transesterification with supercritical alcohol provides a new way of producing biodiesel. Microwave and ultrasound assisted transesterification significantly can reduce reaction time as well as improve product yields. Another process, a plasma technology is promising for biodiesel synthesis from vegetable oils due to very short reaction time, no soap formation and no glycerol as a by-product. This paper reviews briefly the technologies on transesterification reaction for biodiesel production using homogeneous, heterogeneous, and enzyme catalysts, as well as advanced methods (supercritical, microwave, ultrasonic, and plasma technology). Advantages and disadvantages of each method were described comprehensively. Copyright (c) 2016 BCREC GROUP. All rights reserved
\end{abstract}

Keywords: biodiesel; transesterification; advantage and disadvantage; catalytic and non-catalytic process; plasma technology; plasma reactor; catalytic-plasma reactor

How to Cite: Buchori, L., Istadi, I., Purwanto, P. (2016). Advanced Chemical Reactor Technologies for Biodiesel Production from Vegetable Oils - A Review. Bulletin of Chemical Reaction Engineering \& Catalysis, 11 (3): 406-430 (doi:10.9767/bcrec.11.3.490.406-430)

Permalink/DOI: http://doi.org/10.9767/bcrec.11.3.490.406-430

\section{Introduction}

Demand for alternative fuels or biofuels increases significantly as a result of environmental problems, decreasing resources of fossil fuels, and the high price of crude oil. Biodiesel is a renewable resource. It is an alternative fuel made from vegetable oils or animal fats. This fuel is a mixture of fatty acid methyl esters (FAMEs) has lower emissions than petroleum diesel [1]. In fact, the biodiesel is biode-

* Corresponding Author.

E-mail: istadi@che.undip.ac.id (I. Istadi)

Telp.: +62-247460058 Fax.: +62-2476480675 gradable, safe, renewable, non-toxic, containing low sulfur compounds, high flash point $(>130$ $\left.{ }^{\circ} \mathrm{C}\right)$, less carbon monoxide and hydrocarbon emissions than petroleum diesel when combusted, and giving small contribution against greenhouse gasses [2-7]. In its utilization, the biodiesel has physical properties similar to fossil diesel fuel [8]. Therefore, it can be used as fuel instead of diesel oil in boilers and internal combustion engines $[9,10]$.

Transesterification (also called alcoholysis) is the reaction between vegetable oils or animal fats with alcohol into esters and glycerol. The alcohols used in the transesterification are ethanol, methanol, and butanol. Alkyl esters 
are formed during the reaction, i.e. methyl esters, ethyl esters, and butyl esters, respectively $[1,4]$. The transesterification reaction can be carried out with a catalyst, acid or base catalysts [11]. Vegetable oils were widely used as raw material for biodiesel production, including palm oil [12-14], soybean oil [15-17], rapeseed oil [18], jatropha curcas oil [19,20], sunflower oil [21], canola oil [22], waste cooking oil $[23,24]$, or others. The transesterification of triglycerides produces fatty acid alkyl esters and glycerol. Stoichiometrically, the transesterification reaction requires 3 moles of alcohol and 1 mole of triglycerides. This reaction is reversible so that excess alcohol was needed to shift the equilibrium towards the products [1]. As a result, the forward reaction is pseudo-first order and the reverse reaction is second order [25].

Transesterification can be performed using catalytic or non-catalytic reaction with different heating systems. The examples of catalytic reactions are alkali and acid catalyzed as well as enzymatic transesterifications. The use of microwave irradiation, ultrasonic and plasma technologies to enhance the transesterification reaction process can be used whether with catalyst and/or without catalyst. The most commonly preferred homogeneous acid catalysts were sulfuric, sulphonic, and hydrochloric acids, while sodium hydroxide, sodium methoxide, and potassium hydroxide were used as homogeneous alkaline catalysts [26-34]. The homogeneous alkaline catalyst was often used in the process due to needs a shorter time than the homogeneous acid catalyst to achieve high conversion. However, the homogeneous alkaline catalyst can only be used for refined vegetable oils with a less than 0.5 wt.\% FFA [35] or an acid value less than $1 \mathrm{mg} \mathrm{KOH} / \mathrm{g}$ [36]. If the oil or the fat contains high FFA, the FFA will react with the alkaline catalyst to form soap. This reaction can drastically lower the yield of fatty acid methyl ester (FAME) [37,38]. On the contrary, the acid catalysts are not affected by the FFA in the feedstock and the acid catalysts can simultaneously catalyze both esterification and transesterification [39]. However, one drawback of the acid catalyst is longer reaction time and higher molar ratio of alcohol/oil (up to 245:1) [29].

Transesterification using homogeneous catalysts requires more purification stages because it produces a large wastewater and is the biggest drawback of the homogeneous catalysts [11]. Therefore, the many problems associated with homogeneous catalysts can be overcome by heterogeneous catalysis usage although slower the reaction rate. The heterogeneous catalysis can cope the high cost and length of time of water washing and neutralization steps to separate and recover the spent catalyst [40]. Even for the low quality of raw materials, the heterogeneous acid catalyst can handle it, because these catalysts can catalyze both transesterification and esterification reactions simultaneously [41]. The use of this catalyst is quite good because it is less corrosive, less toxic, and does not cause environmental problems [42]. However, the rate of reaction is slower and having a possibility of unwanted side reactions [43]. The transesterification reaction using alkaline solid heterogeneous catalysts showed better catalytic activity compared to a solid acid catalyst $[39,44]$. The heterogeneous alkali transesterification is also more interesting in biodiesel production than the homogeneous system due to the simpler production and purification processes. This heterogeneous catalyst can be reused, lower reaction temperature, and shorter reaction time $[45,46]$. However, the use of an alkaline solid catalyst is limited by free fatty acid usually contained in the low quality feedstock.

The weakness of the heterogeneous alkali transesterification can also be overcome using a biocatalyst (enzymatic catalyst). This process produces very high purity products and lower or no downstream process [47]. Glycerol as a by-product can be easily recovered using enzymatic transesterification without any complicated process. However, biocatalysts need more stringent reaction conditions and require a longer reaction time and higher production cost than alkaline catalyst $[48,49]$. The method has not been applied on an industrial scale yet because of the high price of enzymes, enzyme inhibition by methanol, and exhaustion of enzyme activity $[4,47,50]$.

Transesterification of vegetable oil with noncatalytic supercritical alcohol provides a new way of producing biodiesel due to the reaction of free fatty acids and triglycerides simultaneously. The process does not require a catalyst and takes place in a shorter reaction time and almost no sensitivity to water content. Besides, this method is susceptible to polymerization [51]. Several weaknesses of supercritical alcohol technology are the high cost of processing equipment, high energy requirement, and high pressure and temperature leading to safety issue [52]. This process also requires extreme reaction temperatures and pressures so that purification step becomes difficult due to the increase in viscosity. To overcome the high cost and energy consumption, transesterifica- 
tion process used two-stage supercritical reaction, instead of conventional single-step reaction [51,53]. Meanwhile, the utilization of cosolvents, such as carbon dioxide, hexane, and calcium oxide, can decrease the reaction temperature and pressure [54-56]. However, the supercritical technology is a high-risk process and unsafe. If there were any leakages on the reactor at the reaction pressure higher than 8.1 $\mathrm{MPa}$ would adequate to cause catastrophe effect [52].

One of the advanced technologies for producing biodiesel via transesterification reaction is microwave irradiation assisted process. Within the microwave irradiation technology, the smallest degree of variance of polar molecules and ions, such as alcohol, is activated by the continuously changing magnetic field. The changing electrical field, which interacts with the molecular dipoles and charged ion, causes these molecules or ions to have a rapid rotation and heat is generated due to molecular friction. Therefore, the microwave irradiation accelerates the chemical reaction and produces products with high yields in a shorter time [57,58]. However, microwave irradiation technology for biodiesel synthesis has some weaknesses in the process scale-up from laboratory to industrial scale and process safety [4]. The advantages of microwave irradiation are shorter reaction time, lower oil/methanol ratio, less energy consumption and environmentally benign.

Another advanced technology in biodiesel synthesis is the ultrasound assisted process. This technology has been proven to be able to increase the reaction rates in various reaction systems. Transesterification of triglyceride with alcohol is carried out at low-frequency ultrasonic irradiation. The ultrasonication provides the mechanical energy and the activation energy for mixing and initiating the transesterification reaction, respectively [59]. Advantages of the ultrasonic assisted transesterification reaction are the reduction of reaction time, the low energy consumption [60], the low molar ratio of methanol to triglyceride, and the simple process [4,61]. However, the free-radical production on ultrasound technology, which would accelerate the reaction, does not seem to play a role in base-catalyzed methanolysis carried out under $20 \mathrm{kHz}$ ultrasound at the ambient temperature $(27 \circ \mathrm{C})$ [62]. The ultrasound irradiation also causes the leaching of some solid catalysts at high catalyst loadings [63].

The latest novel advanced technologies potential for biodiesel production are using plasma technology. The most review studies on previous works of literature were only focused on the conventional homogeneous and heterogeneous method for biodiesel production [1,4,25, $38,46,48,49,50]$. Only a few researchers have focused on the advanced technologies for producing biodiesel especially about utilization of plasma processing [64-66]. The potential of the plasma technology is the utilization of high energetic electrons due to a collision between the high energetic electrons and the reaction mixtures. The high energetic electron is supplied from a high voltage power supply through high voltage electrode [66]. Therefore, this paper

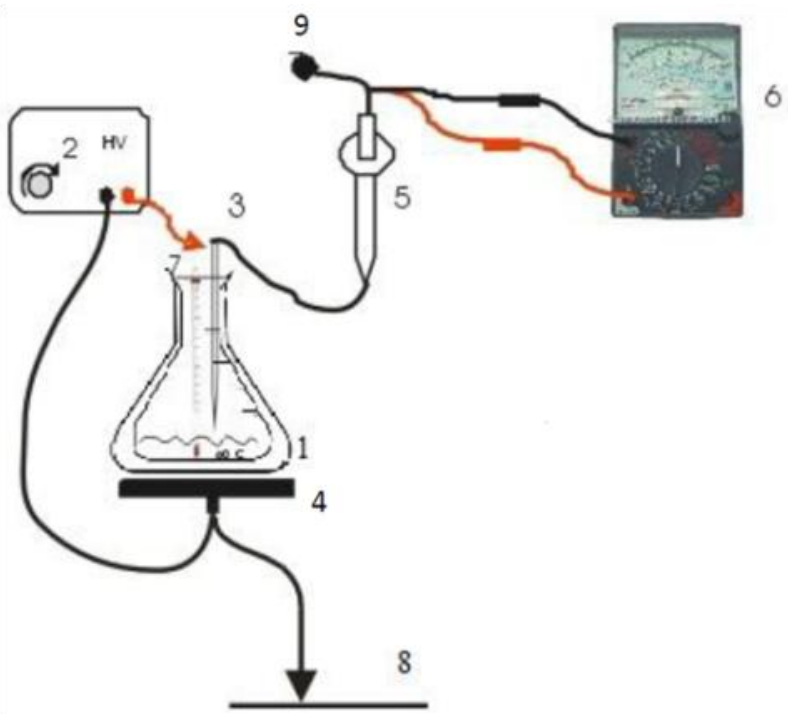

Figure 1. Schematic diagram of plasma electro-catalysis assisted transesterification process: (1) plasma reactor, (2) high voltage power supply, (3) high voltage electrode, (4) ground electrode, (5) high voltage probe, (6) multimeter, (7) thermometer, (8) earth ground, (9) high voltage probe ground.

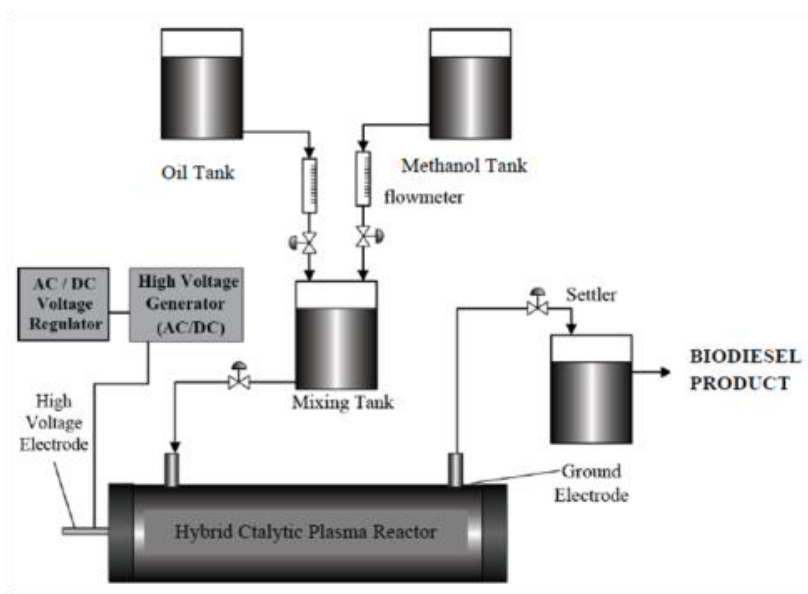

Figure 2. A schematic diagram of hybrid catalytic plasma reactor system in the future work. 
aims to study the overview advanced biodiesel production technologies, including plasma, ultrasound, and microwave, as well as in comparison to conventional homogeneous and heterogeneous catalysis. This technology has developed for both non-catalytic and catalytic plasma. The advantages of this plasma electrocatalysis system only require very short time reaction, does not need a catalyst, does not form soap, and does not produce glycerol as a by-product. However, the main reaction mechanisms were difficult to be controlled during the plasma process due to the action of high energetic electrons [66]. This study gives a contribution on mapping all biodiesel production researches from recent novel technology (plasma, microwave, and ultrasound) to conventional heterogeneous and homogeneous processes. The basic scientific features, advantages, and disadvantages, and potentials of the technologies are highlighted. The main target of advanced technology development in biodiesel production are lower reaction time economically, a small amount of catalyst needed, and economical equipment and operating conditions.

\section{Potential of Advanced Chemical Reac- tors Technologies for Biodiesel Synthesis}

Previous researchers have proposed various reactors technologies for transesterification reaction. In this advanced technology, a novel plasma reactor for biodiesel synthesis from different vegetable oils has been developed by Istadi et al. [66], an author group of this article. The plasma electro-catalysis assisted transesterification process was performed in a dielectric barrier discharge (DBD) plasma reactor. The DBD plasma reactor consists of a high voltage electrode, a ground electrode, a

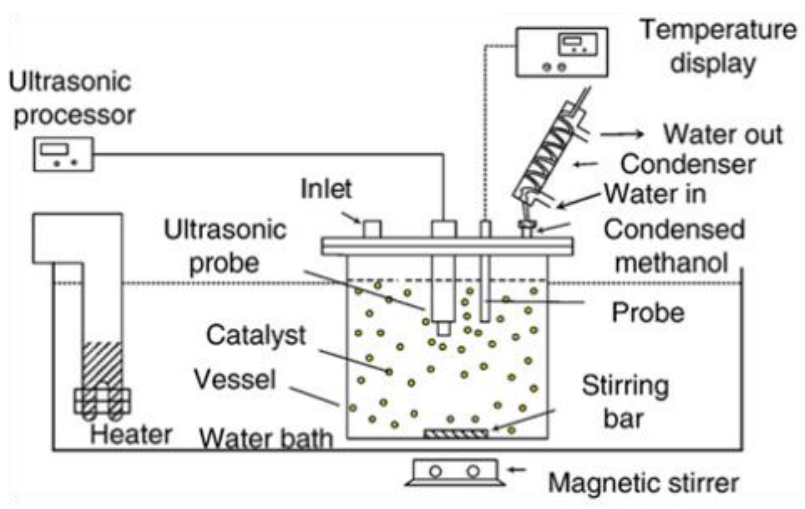

Figure 3. Schematic diagram of the ultrasound transesterification system. (Adapted from Ref. [67] with permission)
DC-type high voltage power supply, a high voltage probe, and a barrier of glass material. The dielectric glass barrier was placed adhere to the ground electrode. The voltage during the reaction process is measured with a multimeter. The reactor is heated to $65{ }^{\circ} \mathrm{C}$ below the boiling point of methanol. The distance between the high voltage electrode and a ground electrode of $1.5 \mathrm{~cm}$. The high energetic electrons flowed from high voltage electrode to ground electrode through the glass barrier in which electrons are distributed by a glass barrier to the ground electrode. A schematic diagram of plasma electro-catalysis assisted transesterification process is depicted in Figure 1.

Concerning the hybrid plasma-catalytic reactor system, the use of simultaneous roles catalytic and plasma processes is interesting due to an expectation of assisting the catalysis process by high energetic electrons in molecular level [66]. There is synergetic effect between plasma system (containing high energetic electrons, excited atoms, and neutral particles) with heterogeneous surface catalysis roles. The synergism is possible in activating the reactants in the discharge zone or even to assist cracking the covalent bonding of reactants before the main reaction takes place and finally giving a positive effect on the reaction mechanism and the reaction rate. A schematic diagram of hybrid catalytic plasma reactor system in the future work can be seen in Figure 2.

In another advanced reactor systems, several researchers have developed a design of ultrasonic assisted transesterification reactor as one of advanced technology for biodiesel production [62,67-70]. A schematic diagram of the ultrasound reactor was proposed by Salamatinia et al. [67] as shown in Figure 3. Salamatinia et al. [67] applied ultrasonic processor in the heterogeneous transesterification of palm oil. The transesterification reaction was carried out in three-neck glass batch reactor equipped with an ultrasonic transducer and probe, a condenser, a magnetic stirrer, a thermocouple thermometer, an ultrasonic processor and a water bath. To maintain the temperature at $65^{\circ} \mathrm{C}$, the glass reactor vessel was placed in a water bath. All the experimental runs were carried out in the presence of air under atmospheric pressure. Carmen et al. [68] investigated a bench scale continuous process for the biodiesel production from neat vegetable oils under high-power low-frequency ultrasonic irradiation. The installation consists of oil, methanol, and catalysts, pumps for oil and methanol catalyst solution, separator, power supply, an ultrasonic transducer and an ultrasonic reactor. The sonochemical reaction cham- 
ber consists of two glass cylinder reactors having a volume of approximately $2.62 \mathrm{~L}$ and 6.35 $\mathrm{L}$, respectively. Push-pull ultrasonic transducer having a frequency of $45 \mathrm{kHz}$. Total power supplied ultrasonic irradiation of $600 \mathrm{~W}$. Temperature of the reaction was $38-40{ }^{\circ} \mathrm{C}$. The excess heat was dissipated by circulating cold water through the cooling jacket. Kalva et al. [62] have studied an application of ultrasound for biodiesel synthesis from soybean oil with sodium hydroxide as the base catalyst. The experimental equipment used in the synthesis of

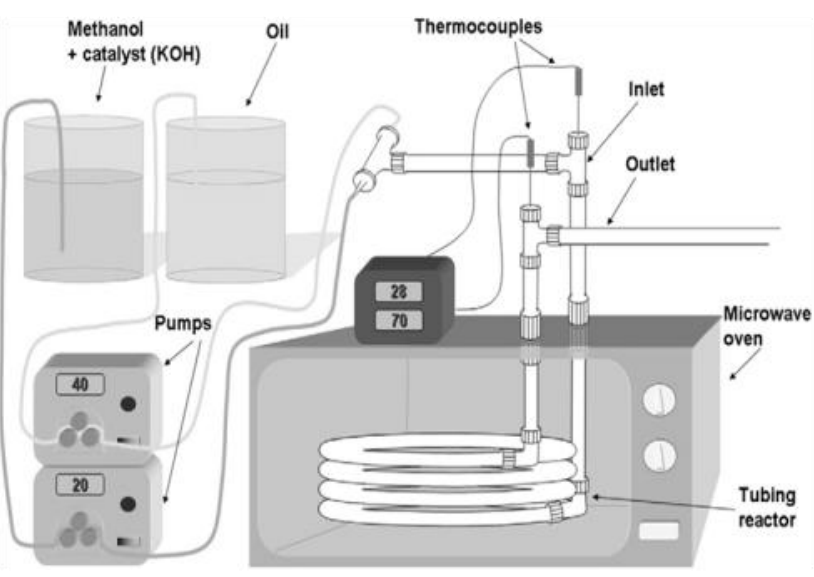

Figure 4. Microwave flowsystem for biodiesel production. (Adapted from Ref. [73] with permission)

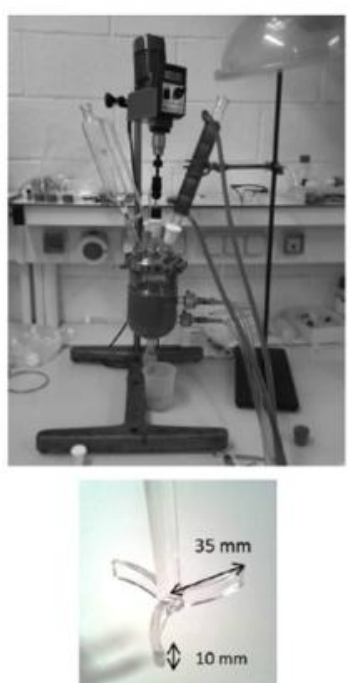

(a)
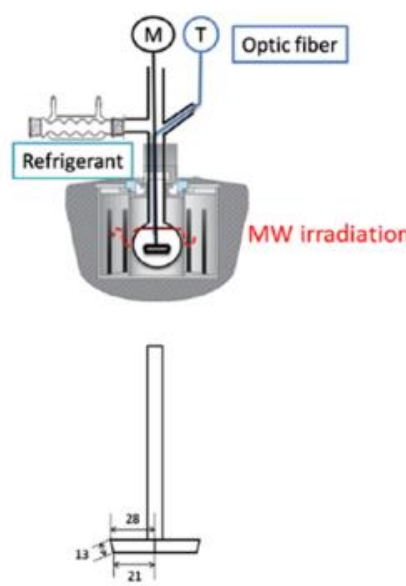

(b)

Figure 5. Two experimental systems: (a) the conventionally heated reactor and its agitator and (b) the microwave heated reactor with its mechanical agitator (M) and temperature monitored by optical fiber (T). Dimensions are given in mm. (Adapted from Ref. [74] with permission) biodiesel composed of borosilicate glass beaker, water bath, laboratory jack, ultrasonic probe (sonicator), and ultrasonic processor. Experiments were carried out in beaker. Sonication of the reaction medium using a microprocessorbased and a programmable ultrasonic processor that has variable power output control. There is automatic tuning and frequency control in the processor. The reaction vessel was placed on a laboratory jack in order to get the precise position of the ultrasonic probe. The actual ultrasound intensity in the medium was determined using calorimetry that generate an acoustic wave in the ultrasound probe [62]. However, all the ultrasound assisted reactor usage is still implemented in lab scale and requires longer reaction time. The ultrasound technology only gives role on assisting mechanical mixing process of the transesterification reaction.

Another advanced technology is a synthesis of biodiesel using microwave assisted reactor, as another advanced technology, has been developed by several researchers [5,58,71-73]. Azcan and Danisman [58] used a Start S-model microwave unit to carry out the transesterification process of cottonseed oil in the presence of methanol and potassium hydroxide. The system was equipped with magnetic stirrer bar for continuous stirring and non-contact infrared continuous feedback temperature system for constant temperature control. Another researcher, Barnard et al. [5], used a multi-mode microwave apparatus (CEMMARS) to study continuous preparation of biodiesel. The transesterification reaction was carried out for new or used vegetable oils with a molar ratio of methanol to oil of $6: 1$. This apparatus consists

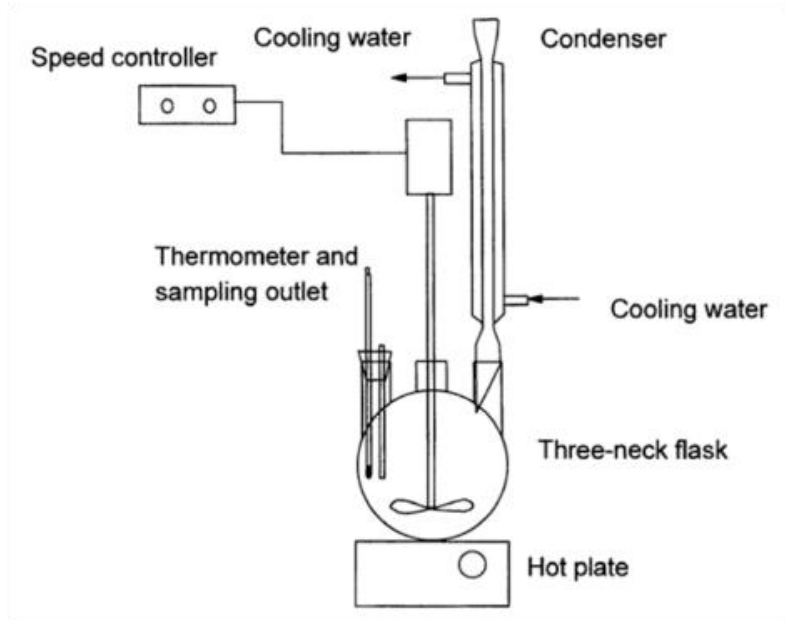

Figure 6. Transesterification batch reactor apparatus. (Adapted from Ref. [75] with permission) 
of a continuous microwave power delivery system with an operator-selectable power output from 0 to $1600 \mathrm{~W}$. The reaction was carried out in either a 2 or $4 \mathrm{~L}$ reactor vessel. The reactor equipped with a polypropylene inlet tube was placed $2.5 \mathrm{~cm}$ from the bottom, and a polypropylene outlet tube was placed $2.5 \mathrm{~cm}$ from the top. A fiber optic probe inserted directly into

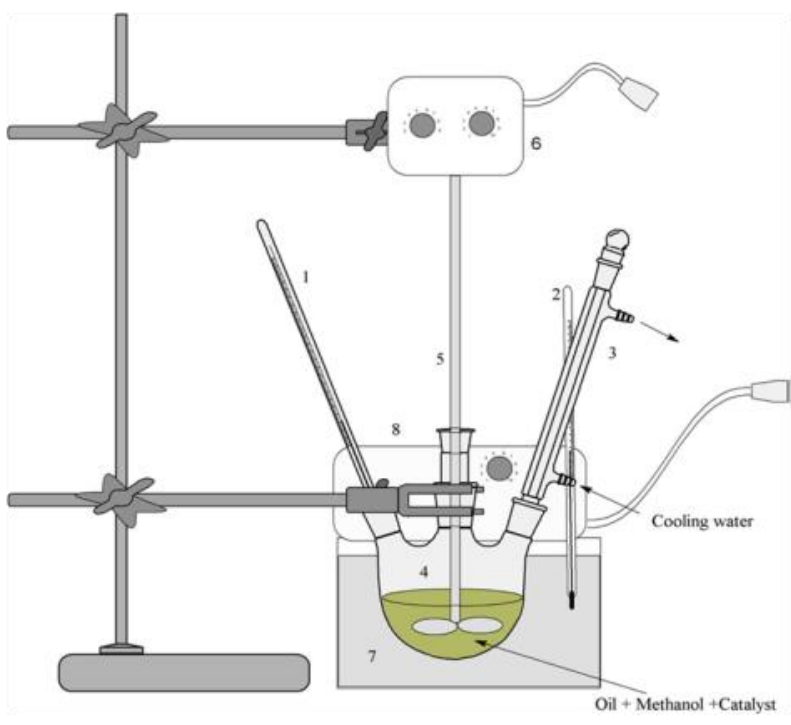

Figure 7. Schematic reaction apparatus for batch-production of biodiesel: (1) and (2) thermometers, (3) condenser, (4) glass reactor, (5) Teflon stirrer, (6) agitation motor, (7) hotwater bath, (8) thermostat heat control unit. (Adapted from Ref. [76] with permission) the reaction mixture using a Teflon thermowell to monitor the temperature of reactants in the vessel. Reactants in the vessel were stirred by a rotating magnetic plate and a Teflon-coated magnetic stir bar. Varying pump speed was used to monitor the microwave power consumption [5].

Encinar et al. [73] investigated the continuous transesterification method of soybean oil by using microwave irradiation. This system consisted of a reactor made of a polytetrafluoroethylene (Teflon). The reactor, equipped with a coil, was installed into the microwave oven and connected to the inlet pumps and the outlet reservoir at the back of the oven. The household microwave with a power of $700 \mathrm{~W}$ was used as an oven. Two holes were drilled at the top oven for inlet and outlet. For monitoring the temperature, two thermocouples were inserted at the inlet (at room temperature) and outlet points, out of the oven, and connected to a digital thermometer. This microwave continuous flow system is depicted in Figure 4.

Mazubert et al. [74] have investigated comparison between the conventionally- and the microwave-heated reactor. The conventionally heated reactor is shown in Figure 5(a), while the microwave reactor is depicted in Figure 5(b).

The conventionally heated reactor consisted of a 1 L-jacketed vessel, a 3-bladed paddle, a cooling system and a mercury thermometer. The cooling system was used to avoid the va-

Table 1. The comparison among advanced reactor technologies for biodiesel processing

\begin{tabular}{|c|c|c|c|}
\hline \multirow[b]{2}{*}{ Parameter } & \multicolumn{3}{|c|}{ Typical performance of the advanced reactor technologies } \\
\hline & $\begin{array}{c}\text { Plasma without } \\
\text { catalyst }\end{array}$ & Ultrasound & Microwave \\
\hline Oil & Palm Oil & Palm oil & Soybean oil \\
\hline Alcohol & Methanol & Methanol & Methanol \\
\hline Reaction condition & Temp.: $65^{\circ} \mathrm{C}$ & Temp.: $65^{\circ} \mathrm{C}$ & Temp.: $70^{\circ} \mathrm{C}$ \\
\hline Catalyst & No catalyst & $\mathrm{BaO}, \mathrm{SrO}$ & $\mathrm{KOH}$ \\
\hline $\begin{array}{l}\text { Molar ratio of } \\
\text { alcohol : oil }\end{array}$ & $6: 1$ & $9: 1$ & $12: 1$ \\
\hline Reaction time & $1-2 \min$ & $50 \mathrm{~min}$ & $2 \min$ \\
\hline Reactor type & $\begin{array}{c}\text { Dielectric Barrier } \\
\text { Discharge (DBD) } \\
\text { plasma reactor }\end{array}$ & $\begin{array}{l}\text { Three-neck glass } \\
\text { batch reactor which was } \\
\text { equipped with an ultrasonic } \\
\text { transducer and probe, a } \\
\text { condenser, a stirrer and a } \\
\text { thermocouple thermometer }\end{array}$ & $\begin{array}{c}\text { Poly- } \\
\text { tetrafluoroethylene } \\
\text { (Teflon) tubing reactor } \\
\text { of } 28 \mathrm{~mm} \text { ID and } 150 \\
\text { mL of total volume, } \\
\text { which was coiled into } \\
\text { the microwave oven }\end{array}$ \\
\hline $\begin{array}{l}\text { Yield of } \\
\text { FAME/biodiesel }\end{array}$ & $\begin{array}{c}75.65 \% \text { (yield of } \\
\text { FAME) }\end{array}$ & $94 \%$ (yield of biodiesel) & $99 \%$ (yield of FAME) \\
\hline
\end{tabular}


porization of methanol. The microwave reactor was equipped with a $100 \mathrm{~mL}$ round flask and a 2-bladed paddle impeller and operated at atmospheric pressure. The microwave reactor has the default magnetic stirrer. However, this device was unable to rotate in the viscous oils $\backslash$ so that provided insufficient mixing. Therefore, the conventional magnetic stirrer was replaced with the 2-bladed paddle impeller to ensure good mixing of the reactants and homogenize the temperatures in the microwave cavity. The power was automatically adjusted to the measured temperature via an optical fiber. The temperature homogeneity was also assisted by the use of a single mode microwave reactor, instead of a multimode reactor type [74]. The comparison of advanced reactor technologies for biodiesel process is presented in Table 1 .

Biodiesel reactors used for the conventional catalytic transesterification have been developed by some previous researchers [75-81]. Ma et al. [75] developed a batch reactor for transesterification of beef tallow and methanol using a homogeneous alkaline catalyst. The reactor consisted of three neck distillation flask, equipped with a condenser, a mechanical stirrer with a speed that can be controlled, thermometer, sampling outlet and hot plate. After the transesterification reaction was complete, the flask was removed from the hot plate, and the product of the reaction was settled. Then, the samples were taken from the reaction flask for analysis. Batch reactor apparatus used in this study is depicted in Figure 6.

Meanwhile, a batch reactor for the biodiesel production with heterogeneous catalyst was proposed by Endalew et al. [76] as shown in Figure 7. Apparatus for the batch production of biodiesel consisted of glass reactor, condenser, water bath, thermostat heat control unit, thermometers, stirrer, and agitation motor. A three-neck flask was used as the reactor was placed in a water bath. The temperature of reaction and water bath was measured using a thermometer inserted in the reactor and the water bath. A thermostat was used to control the temperature in a water bath is kept constant. Cooling process was done using the condenser. Reactant mixture was stirred using a Teflon stirrer driven by an electric motor.

The other researchers have developed reactor system for continuous transesterification process, such as Darnoko and Cheryan [77], Hsieh et al. [78], Ren et al. [80], and da Silva et al. [81]. Darnoko and Cheryan [77] developed a system for continuous transesterification of palm oil using a continuous stirred-tank reactor (CSTR) as presented in Figure 8. Apparatus for continuous transesterification of palm oil consists of a 1-L reactor, condenser, tank for the feed (oil) and the catalyst, three pumps for the oil, catalyst, and product streams, thermometer, heater, stirrer, and funnel separator for separating the methyl esters from glycerol. Heating was provided by a water bath where a thermostat controls the temperature.

Hsieh et al. [78], Feng et al. [79], Ren et al. [80], and da Silva et al. [81] investigated biodiesel production using a fixed bed reactor. Hsieh et al. [78] studied the continuous production of biodiesel in a steady-state packed bed reactor using shell-core $\mathrm{Ca}\left(\mathrm{C}_{3} \mathrm{H}_{7} \mathrm{O}_{3}\right)_{2} / \mathrm{CaCO}_{3}$

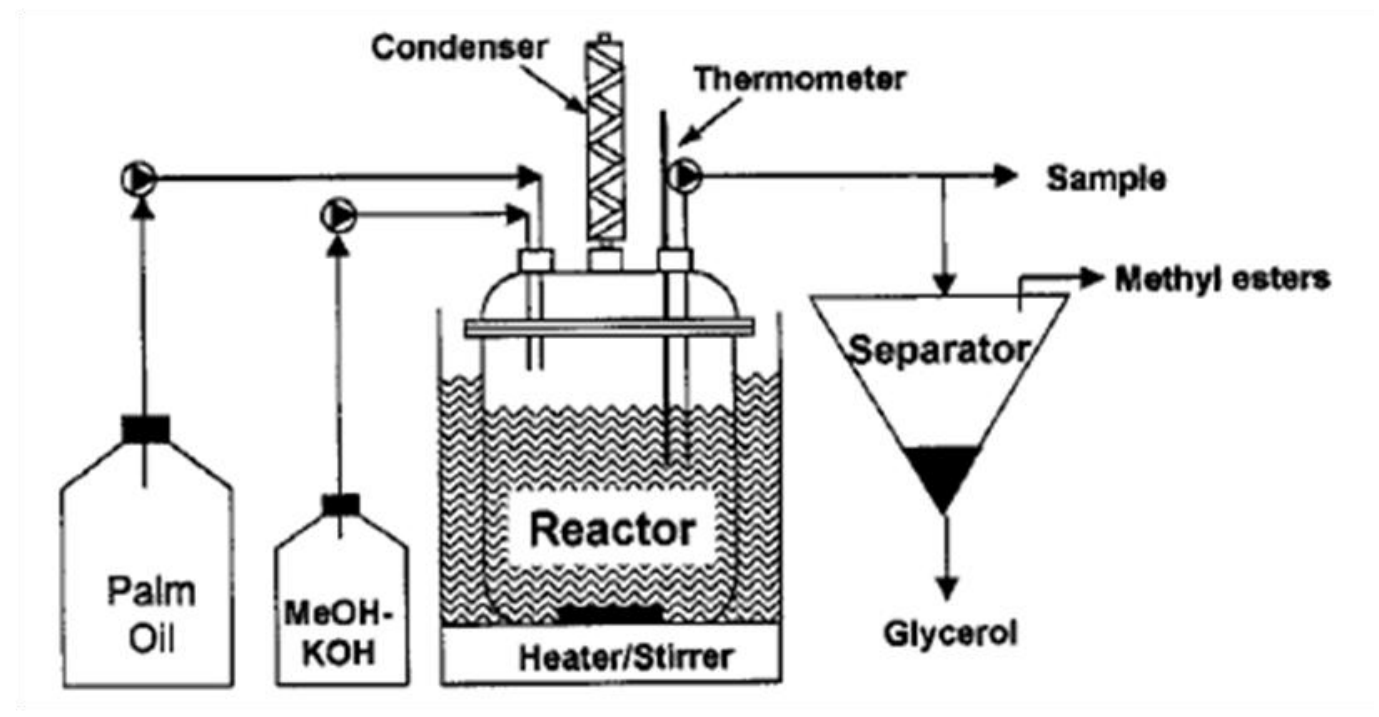

Figure 8. Experimental set up for continuous transesterification of palm oil. (Adapted from Ref. [77] with permission) 
solid base catalyst. Experimental setup of packed bed reactor consisted of a cylindrical reactor, mechanical stirrer, HPLC pump, heating tape, thermocouple, temperature controller, four-neck flask, and sample collector. Reactants mixture (soybean oil and methanol) is stirred with a mechanical stirrer in a four-neck flask, then the feed was pumped with an HPLC pump is inserted into the reactor. Thermocouple monitors the temperature of the reactor. Periodically, samples were collected in glass bottle located in the reactor output and then analyzed by GC.

Feng et al. [79] and Ren et al. [80] proposed continuous reactor using a fixed bed reactor. Feng et al. [79] used fixed bed reactor for the continuous esterification, while Ren et al. [80] used fixed bed reactor for the continuous transesterification. The scheme of the fixed bed reactors was shown in Figure 9(a). The reactor was composed of stainless steel column, feedstock tank, accumulation tank, thermostat water bath, heater, and peristaltic pump. Stainless steel column had $25 \mathrm{~mm}$ internal diameter and $450 \mathrm{~mm}$ height and was equipped with a waterjacketed. The column was packed with pretreated NKC-9 cation exchange resin for esterification and the activated D261 anion exchange resin for transesterification. The reactants (oil and alcohol) were mixed in a feedstock tank and preheated with a heater. Then feed was introduced into the reactor using a peristaltic pump. The reaction temperature inside the re- actor was kept constant by a thermostat water bath. Effluent from the reactor outlet was collected into an accumulation tank. The excess alcohol, co-solvent, and water obtained during the reaction was removed from the sample by reduced pressure distillation. The left sample was collected for the conversion and composition measurement $[79,80]$.

da Silva et al. [81] developed a fixed bed tubular continuous reactor using pellets of aluminum oxide doped with zinc oxide to produce biodiesel. The scheme and picture of the continuous transesterification system are depicted in Figure 9(b). The system consisted of ethanol and soybean oil tanks, mass flow controllers, tubular reactor, static mixer, needle valve, heat exchanger, and product collection tank. Alcohol and oil flowed through the system and controlled digitally by flow controllers that placed between the tanks and the static mixer. Alcohol and oil were mixed and put into fixed bed. The catalyst pellets of $2.6 \mathrm{~kg}$ were filled into a tubular reactor along approximately 30 $\mathrm{cm}$. Glass balls with a diameter of $1 \mathrm{~cm}$ was loaded at the initial section of the reactor along the $30 \mathrm{~cm}$ to preheating the reactants before contact with the catalyst bed. Two heating jackets that placed along the external surface of the reactor was used to heat the reactor. The temperature in the system was controlled digitally by using the signals of three thermopars placed inside the reactor and each jacket. The output flow was controlled manually using a

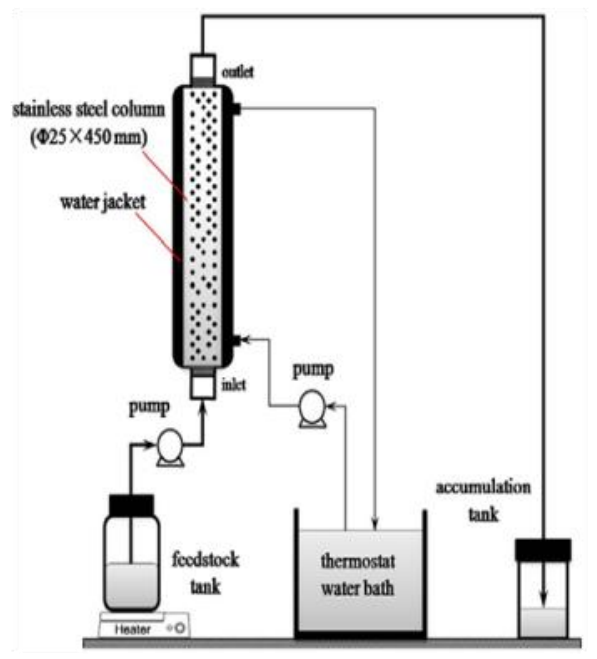

(a)

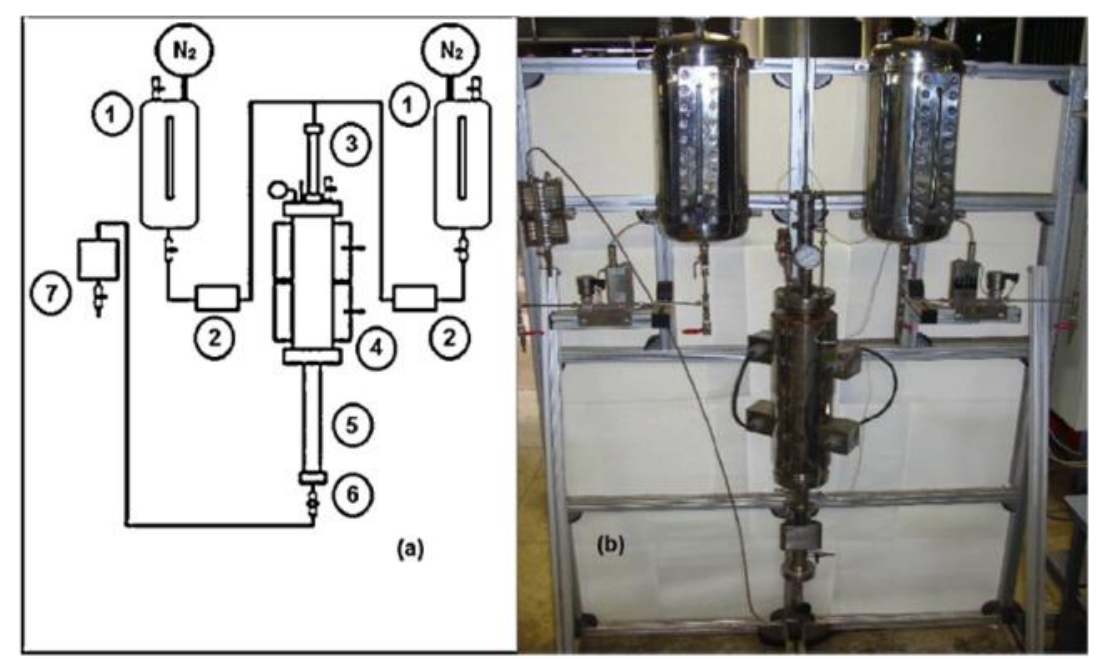

(b)

Figure 9. Packed bed reactor for biodiesel production: (a) Scheme of the experimental apparatus used for the continuous esterification and transesterification; (b) Scheme (a) and picture (b) of the continuous transesterification system: (1) alcohol and oil storage tanks; (2) massflow controller; (3) static mixer; (4) tubular reactor; (5) heat exchanger; (6) needle valve; (7) product collection tank. (Adapted from Refs. [79,80,81] with permission) 
needle valve at the end of the tubular reactor. Then the mixture was cooled and collected in the tank [81].

Another potential technology is supercritical methanol transesterification system studied by several researchers, such as Demirbas [8], Yin et al. [82], and Micic et al. [83]. These researchers used the same type of reactor, namely highpressure autoclave reactor. Demirbas [8] conducted experiments in a cylindrical autoclave. This reactor made of 316 stainless steel. Pressure and temperature were monitored in real time, which included up to $100 \mathrm{MPa}$ and $850 \mathrm{~K}$, respectively. The samples were fed into the autoclave, and the hole was plugged with a screw bolt after each run. An external heater heated the autoclave, and the power was adjusted to give an approximate heating time. Iron-constantan thermocouple was used to measure the temperature of the reaction vessel. After each run was completed, the gas was released, and the autoclave content was poured into a collecting vessel. The rest of the contents in the autoclave was washed with methanol [8].

Yin et al. [82] proposed supercritical methanol transesterification with co-solvent as shown in Figure 10. Transesterification used an autoclave reactor made of stainless steel with a capacity of $250 \mathrm{~mL}$. The reactor was equipped with a magnetic stirrer and internal cooling system. The liquid solution in the reactor was stirred and heated to the desired temperature with an external electrical furnace. The reactor operated at a temperature of $120-350{ }^{\circ} \mathrm{C}$ and pressure of 7-25 $\mathrm{MPa}$. The temperature was measured using a thermocouple and automatically controlled by a temperature control. The pressure indicated by a pressure sensor. The reactor was transferred into an ice-water bath after completion of the reaction to quench the reaction. Then, the autoclave was opened, and the reaction mixture poured into a collecting vessel. The reaction mixture was evaporated with a rotary evaporator to eliminate the methanol. The sample was settled to separate methyl ester and glycerin. Methyl ester occupied the upper part, while the bottom part was occupied by glycerin [82]. Transesterification of rapeseed oil in different alcohols using supercritical was carried out in a batch reactor by Micic et al. [83]. The reactor was equipped with an electric heater that can heat the sample up to $350{ }^{\circ} \mathrm{C}$.

\section{Plasma Reactor Technology in Trans- esterification Process for Biodiesel Pro- duction}

Plasma technology is a novel technology used in gas processing including hydrocarbon processing to produce valuable chemicals and fuels [64,84-93]. Plasma or commonly called non-thermal plasma is a fourth phase composed of electrons, excited atoms and

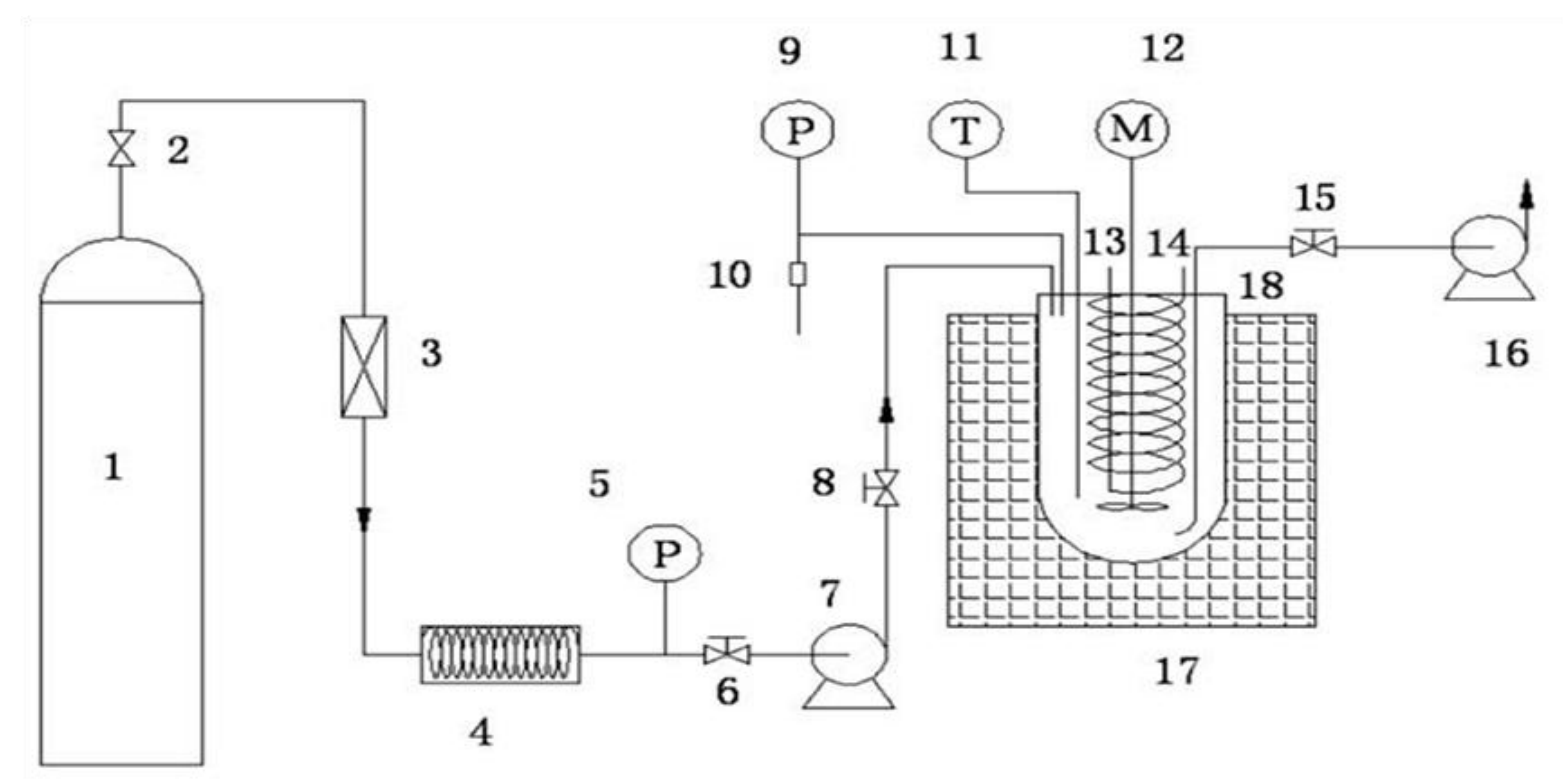

Figure 10. Schematic diagram of supercritical methanol transesterification system with co-solvent (1) $\mathrm{CO}_{2}$ cylinder, (2) regulator, (3) filter, (4) cooling coil, (5) pressure gauge, (6) needle valve, (7) high pressure pump, (8) check valve, (9) pressure control monitor, (10) rapture disc, (11) temperature control monitor, (12) magnetic stirrer, (13) cooling coil inlet, (14) cooling coil outlet, (15) metering valve, (16) wetgas test meter, (17) electrical furnace, and (18) autoclave. (Adapted from Ref. [82] with permission) 
molecules, ions, radicals, photons and neutral particles. In a non-thermal plasma, electrons have a higher energy than the neutral gas particles. Another name of non-thermal plasma is non-equilibrium plasma because of significant differences between electrons and neutral particles from temperature or kinetic energy. As an example, in the dielectric barrier discharge (DBD), the electron temperature can reach $10^{4}-10^{5} \mathrm{~K}$, while the gas temperature may be in the range of room temperature [90,91,93-95].

The mechanism of reaction occurs in the plasma processes which is different to that of conventional reactions. Initially, the highenergy electrons are transferred from the highvoltage electrode to the ground electrode. These electrons collide with the bulk gas molecules causing excitation, ionization and the formation of atoms and metastable compounds. A large number of micro discharges are produced when the electric field is high enough to lead breakdowns. Furthermore, there are collisions between active atoms and metastable compounds with reactant molecules [91,93-97]. As a result, various reactions can occur so that it produces a mixture of compounds with different compositions [85].

In term of production of biodiesel from vegetable oil methanolysis using plasma technology, electrochemical reactions are expected to split the carbon-carbon bonds in the triglyceride reactants wherein the carboncarbon bond is stronger and requires a higher catalytic energy. Additional reactions occur when the higher electrochemical catalytic energy attacks the unsaturated double bonds of triglycerides through oxygenation. Methanol provides oxygen molecules during the reaction process in which oxygen molecules replace each carbon-carbon double bond to generate a saturated molecule that has better thermal storage stability. More high energetic electrons need to be stored in a high voltage power supply where the electron help catalyzing triglyceride methanolysis $[66,85,98,99]$.

Until now, only a few researchers developed biodiesel production using this high voltage plasma technology [64-66]. One of the studies of the plasma technology was conducted by Istadi et al. [66]. Firstly, this research was carried out without a catalyst, called plasma electro-catalysis, in a corona (tip to planar corona plasma reactor). Palm oil was used as a source of triglycerides with methanol/oil molar ratio of $6: 1$ and reaction temperature of $65{ }^{\circ} \mathrm{C}$. Effect of length of time of plasma discharge applied was studied by varying the reaction time of 30,120 , and 300 seconds in the research. Meanwhile, the effect of high voltage was investigated by varying voltages as 6,8 , and $10 \mathrm{kV}$ and effect of electrode gap was investigated by varying the electrode gap as $1.5,2.5$, and $3.5 \mathrm{~cm}$. The results showed that the reaction time of 120 seconds with a voltage of $10 \mathrm{kV}$ and 1.5 distance between the electrode obtain various chemicals, i.e. fatty acid methyl ester (FAME), aldehyde, alkynes, alcohols, esters, and carboxylic acids with FAME yield of 75.65\% [66]. Another researcher, Lawson and Baosman [64] used electrocatalysis to the synthesis of biodiesel. Mostly, the biodiesel synthesis process does not produce a byproduct, only produce hydrogen gas, that needs to be removed from the process and etherified glycerin (1,2,3-propanoat). This method breaks the carbon to carbon bond in triglycerides, thus forming a monoalkyl ester or a separate glyceridic part of triglycerides to form dehydrated glycerol. The addition of excess alcohol etherifies the dehydrated glycerol to form 1,2,3-propanoat. Essentially, reaction yield is $100 \%$ methyl ester.

The above research results indicate that the plasma electrocatalysis is a promising technology for biodiesel synthesis from vegetable oils. This is true because this novel technology only requires very short time reaction, no catalyst needed, no soap formation, and no glycerol as the by-product. However, disadvantages of this system are difficulty in controlling the reaction mechanism, controlling the bond that will be excited or ionized, and prevent continuing reactions. Advantages and disadvantages of this system are presented in Table 2 .

\section{Ultrasonic Reactor Technology in Transesterification Process for Biodiesel Production}

Ultrasound has been proven to be a very useful tool in improving the reaction rates of the various reacting systems. This tool is very helpful for increasing conversion, improving yield in a relatively short time, change the reaction pathways, or initiated the reaction in biological, chemical, and electrochemical systems $[10,60,62,68,69,100-104]$. The ultrasound technology is defined as a sound with a frequency above the frequencies that the human ear can respond. This frequency lies between $20 \mathrm{kHz}$ and $100 \mathrm{MHz}$. The average sound frequencies that can be detected by humans lies between 16 and $18 \mathrm{kHz}$ [4]. Transesterification reaction of triglycerides 
with alcohol can use low-frequency ultrasonic irradiation. This ultrasonic technology provides the mechanical energy for mixing and the needed activation energy for start the transesterification reaction [59].

The reaction between the immiscible liquidliquid phases of methanol and triglyceride can occur only in the interfacial region between the liquids. Mass transfer rate between the immiscible liquid-liquid phases within a heterogeneous system can be enhanced by using a method of the ultrasonic technology $[10,46,60,69,101,105-107]$. In this process, sufficient energy from the ultrasonic power irradiation will create cavities in the immiscible liquids so as to form fine micro bubbles. The asymmetric collapse of cavitation bubbles disrupts the phase boundary, and override of fluid creates a microjet, which causes intensive emulsification system between oil and alcohol [60,62]. Besides, the cavitation may also lead to an increase in local temperature at the phase boundary that can improve the transesterification reaction. Therefore, the ultrasonic technology in the production of biodiesel does not require agitation and heating $[10,104]$.

A large number of bubbles can be generated in the liquid which some of them are stable and resistant to another cycle while others will undergo vigorous breakdown once reaching certain critical size. Breakdown from the bubbles that form at zero time will occur after the forecast period of $400 \mu \mathrm{s}$ [105]. The energy for some chemical reactions can be offered from small hotspots that are generated from these collapses. These phenomena result in severe mixing between the two immiscible liquids close to the phase boundary and force the liquids to inspire micro jets which can reach to speed up to $200 \mathrm{~m} / \mathrm{s}$. The cause for the micro jets generation is the asymmetric breakdown of the cavitation bubbles [60].

The physical and chemical effects on the reaction system of liquid-liquid heterogeneous, triggered by ultrasound technology, generates cavitation bubbles as follows: (1) the physical effect is emulsification, where the micro turbulence generated for radial movement of bubbles, creating an intimate mixing of the immiscible reactants; (2) the chemical effect, in which chemical reaction in the bulk medium would be accelerated by radicals such as $\mathrm{H} \cdot$, $\mathrm{OH} \cdot$, are produced during transient collapse of the bubble. Therefore, the interfacial area between the reactants provides faster reaction kinetics [62].
Transesterification method using ultrasonic technology has less energy consumption compared conventional mechanical stirring. As an example, transesterification of $1 \mathrm{~kg}$ soybean oil using conventional mechanical stirring method consumes $500 \mathrm{~W} / \mathrm{kg}$ of energy, but when using ultrasonic cavitation method only consumes $250 \mathrm{~W} / \mathrm{kg}$ of energy [60]. The advantages and disadvantages of the ultrasonic technology are presented in Table 2.

\section{Microwave Reactor Technology in Transesterification Process for Biodiesel Production}

One of the advanced technology used electromagnetic energy are microwave irradiation. In the microwave irradiation assisted the process, the heat energy is transferred in the form of electromagnetic through convection, conduction, and radiation from surfaces of the raw material $[100,108]$. In conventional heating, heat transfer is rather slower, and the heat energy is not distributed evenly so that preheating and reaction time becomes longer needed. The longer heating causes decomposition of the product due to direct contact between the hot reaction vessel surface with reaction media (reactants) $[108,109]$. In this technology, microwave irradiation is electromagnetic irradiation in the wavelengths range from 0.01 to $1 \mathrm{~m}$ and a frequency range of 0.3 to $300 \mathrm{GHz}$. All microwave reactors for chemical synthesis and all domestic microwave ovens operate at a wavelength of $12.25 \mathrm{~cm}$ with a frequency of $2.45 \mathrm{GHz}[110,111]$. Main problems of the conventional heating, such as limitations on the materials thermal conductivity, heterogenic surface heating, specific heat, and density, can be treated by microwave irradiation. The microwave irradiation requires lesser energy input for heating and reduction of reaction time compared to conventional heating method [58,71,112].

Conceptually, microwaves transfer energy is not conducted in the form of thermal heat reflux but in the form of electromagnetic. During the microwave irradiation, alcohol as polar molecules aligns with the changes in the magnetic field generated by microwaves. The molecules or the ions derived from the interaction between the electrical field with the molecular dipoles and charged ion would have a rapid rotation and heat generated due to molecular friction. The increase in reaction rate is most likely due to the high temperature at the site of local reaction at the catalytic 
surface. This is supposed to accelerate various chemical and physical processes. Microwave treatment brings about a greater accessibility of the susceptible bonds and hence a much more efficient chemical reaction. Hence, microwave irradiation provides energy directly to the reactant so that it will accelerates and enhance the chemical reaction and obtain high product within a shorter reaction time [58]. In the microwave irradiation, the real reaction temperature is higher than the average temperature of the medium due to the formation of localized superheating derived from the interaction of the microwave energy with the molecules at a very fast rate. In consequence, both reaction time and energy consumption are reduced by means of microwave irradiation. Therefore, microwave heating becomes more efficient than the conventional methods [111,113]. The microwave assisted biodiesel production has several advantages and disadvantages as depicted in Table 2 .

\section{Supercritical Fluids Reactor Technol- ogy in Transesterification Process for Bio- diesel Production}

Another method to overcome the problems in conventional catalytic transesterification process is by using supercritical alcohols technology $[8,51,55,56,114-117]$. Transesterification reaction between triglycerides, nonpolar molecules, and alcohol, polar molecules, is categorized as a heterogeneous reaction of two immiscible liquid phases at conventional processing temperatures $[10,46,52,69,105$, $118,119]$. This phenomenon can be overcome by using supercritical conditions in which the mixture is easily made into a homogeneous single phase so that the reaction would be faster due to no interphase mass transfer limitation [118].

The main advantage of this method is that when the feedstock contains water and FFA, three types of reactions namely transesterification, triglycerides hydrolysis, and alkyl esterification of fatty acids occur simultaneously [115]. Besides, the impurities in the feedstock do not need to be treated because it does not affect the reaction strongly [115]. The alkyl esterification process is faster than the transesterification, while, all FFA in feedstock or hydrolysis products are entirely transformed into alkyl ester [120]. This method of supercritical transesterification only takes about 2-4 min of reaction time to reach reaction equilibrium compared the catalytic transesteri- fication process that requires several hours (18 hours) [114,116]. Under supercritical conditions, alcohol has dual roles, i.e. as a reactant and as an acid catalyst [120]. Table 2 shows several advantages and disadvantages from the supercritical transesterification method.

The supercritical transesterification process required a high molar ratio of alcohol to oil (more than 40:1) that would complicate the separation of excess methanol from biodiesel product to be recovered and reused, particularly if used commercially [118]. To overcome this problem, a co-solvents, such as carbon dioxide, hexane, propane and calcium oxide, is added to the reaction mixture with small amount of catalyst and sub-critical alcohol [4]. As a result, by adding co-solvent and $0.1 \mathrm{wt} . \%$ potassium hydroxide can produce up to $98 \%$ yield of methyl ester for 20 minutes with the ratio of methanol/oil of 24:1 [82].

\section{Enzyme Catalyzed Transesterification Process for Biodiesel Production}

Transesterification reaction using an alkalicatalysis process gives a high conversion of triglycerides in shorter reaction times, although the reaction still has several drawbacks as presented in Table 2. However, these problems may be solved by enzymatic transesterification method. The enzyme catalysts, also called as biocatalyst, are obtained from lipase and are produced from microorganisms, animals, and plants. Production of biodiesel using the lipasecatalyzed gets considerable attention from researchers because this method has the potential to be environmentally friendly and economical process in the future [121]. According to the techno-economic analysis of previous researchers, the cost of using enzyme per $\mathrm{kg}$ of ester produced is higher than the cost of using an alkali catalyst (per $\mathrm{kg}$ of ester produced) [1,25,36,48,122]. Advantages and disadvantages of the enzyme catalyst are explained in Table 2.

Transesterification of triglycerides with a lipase enzyme and the alcohol (alcoholysis) consists of a two-step mechanism. The first step is hydrolysis of the ester bond releasing the alcohol moiety. The second step is esterification of the second substrate. The two steps are represented in Equations (1) and (2) [122-125].

$\mathrm{E}+\mathrm{ES}_{\mathrm{S}} \Leftrightarrow \mathrm{E} . \mathrm{ES}_{\mathrm{S}} \Leftrightarrow \mathrm{F} . \mathrm{B}_{\mathrm{p}} \Leftrightarrow \mathrm{F}+\mathrm{B}_{\mathrm{p}}$ (1) followed by:

$$
\mathrm{F}+\mathrm{AS}_{\mathrm{S}} \Leftrightarrow \mathrm{F} . \mathrm{AS}_{\mathrm{S}} \Leftrightarrow \mathrm{E} . \mathrm{Esp} \Leftrightarrow \mathrm{E}+\mathrm{ES}_{\mathrm{p}}
$$


Subscripts $\mathrm{s}$ and $\mathrm{p}$ indicate substrate and product, respectively. For biodiesel, $\mathrm{A}_{\mathrm{s}}=$ alcohol substrate (i.e., methanol or ethanol), $\mathrm{B}_{\mathrm{p}}=$ product with alcohol moiety (di- or monoglyceride or glycerol), $\mathrm{E}=$ free enzyme, $\mathrm{E}_{\mathrm{s}}=$ ester substrate (tri-, di- or monoglyceride), $\mathrm{Es}_{\mathrm{p}}=\mathrm{FAAE}, \mathrm{F}=$ fatty acid.

\section{Conventional Transesterification Proc- ess using Heterogeneous and Homogene- ous Catalysts for Biodiesel Production}

Transesterification process using homogeneous catalysts (liquid phases catalysis) give a good yield of biodiesel. Alcohol and vegetable oil are immiscible due to polarity leading to relatively slower transesterification reaction. The vigorous mixing and stirring are needed as well as higher reaction temperature to improve the solubility between both reactants. Usage of catalyst and heating system increases the reaction rates which in turn improving biodiesel yield due to reducing diffusion limitation [52]. However, the homogeneous reactions have several drawbacks, i.e. complexity and high cost of purification and separation steps of the product, requirement of additional costs to dispose of alkaline and acidic wastewater, difficulty in glycerol recovery due to high solubility of methanol and a catalyst, high energy requirement, and soap formation as by-product $[52,126,127]$. The problems can be overcome by application of solid heterogeneous catalysis system for the transesterification due to the different phases of the catalyst and the products [52]. The heterogeneous catalyst can be reused several times to minimize the material and process costs. The heterogeneous acid catalyst can prevent undesired saponification reactions when the transesterification is carried out using vegetable oils or animal fats with high FFA contents as raw material. The process is more environmentally benign friendly and could be applied to a batch or a continuous process without the need further purification steps [4,40,52,76,128].

Unlike the homogeneous catalysis, the heterogeneous catalysis eliminates the cost and time of water washing and neutralization steps to separate and to recover the used catalyst [40]. The heterogeneous catalysis can produce methyl ester with a purity exceeding 99\% and yield approaching 100\%. Besides, glycerol as a by-product can be generated by the heterogeneous process with a purity of greater than $98 \%$, while homogeneous process only produces glycerol with a purity of about $80 \%$ [119]. The heterogeneous catalysts can be easily adapted to incorporate the desired properties of the catalyst so that the presence of FFA or water does not affect the reaction steps during transesterification process. The production cost of the fatty acid methyl ester (FAME) with the heterogeneous catalysts are cheaper than the homogeneous catalyst due to long lifetime and reusable heterogeneous catalysts as well as possible to carry out both esterification and transesterification simultaneously [40,129].

However, reaction rate of the heterogeneous process is relatively slower than that of the homogeneous reaction due to diffusion limitation problems involving three-phase system of oil, alcohol, and solid catalyst. The presence of water and methanol in the reaction mixture causes the leaching phenomenon of active compounds in the catalysts affecting reduced efficiency and resulting in lower biodiesel yield [126,130].

\subsection{Heterogeneous base catalysis}

Transesterification using heterogeneous base catalysts have attracted attentions of previous researchers. The heterogeneous base catalysts commonly used in the transesterification process are alkaline earth metal oxides, such as $\mathrm{MgO}, \mathrm{CaO}, \mathrm{SrO}$, and $\mathrm{BaO}$ [46], basic zeolites, hydrotalcite [43], mixed metal oxides and derivatives [131]. Promoters are also commonly used for these catalysts that can be derived from alkali metals, such as $\mathrm{Li}, \mathrm{Na}$, and $\mathrm{K}$ [46] to promote basicity of the catalysts. The mechanism of heterogeneous base catalysis (using $\mathrm{CaO}$ as an example catalyst) involves four steps as reported by previous researchers $[132,133]$. Formation of methoxide anion from the reaction of alcohol with the $\mathrm{CaO}$ catalyst occurs in the first step. The formation of the alkoxy carbonyl intermediate is reported in the second step of the reaction. Then, the breakdown of alkoxy carbonyl intermediate into alkyl ester and diglyceride anion in the third step. The last step is the formation of diglyceride. The similar mechanism could be repeated to monoglyceride. Detail of the mechanism schemes can be found in references [138,139].

However, use of the heterogeneous base catalysts is limited by the free fatty acid content. The catalysts can be utilized if the feedstock is in good quality. Several advantages and disadvantages of heterogeneous base catalysts are presented in Table 2 . 
Table 2. Advantages and disadvantages of transesterification processes for biodiesel production

\begin{tabular}{|c|c|c|c|}
\hline Method & Advantages & Disadvantages & Ref. \\
\hline $\begin{array}{l}\text { Plasma-electro } \\
\text { catalysis (without } \\
\text { catalyst) }\end{array}$ & $\begin{array}{l}\text { very short time reaction } \\
\text { does not require a catalyst } \\
\text { does not form soap } \\
\text { does not produce glycerol as a by-product }\end{array}$ & $\begin{array}{l}\text { difficult to control the reaction mechanism due to the } \\
\text { action of high energetic electrons } \\
\text { difficult to control the bond that will be excited or } \\
\text { ionized } \\
\text { difficult to prevent continuing reactions due the action } \\
\text { of high energetic electrons }\end{array}$ & [66] \\
\hline Ultrasound & $\begin{array}{l}\text { increasing the speed of chemical reactions and the } \\
\text { conversion reaction } \\
\text { high yield of biodiesel } \\
\text { short reaction time } \\
\text { low energy consumption } \\
\text { low molar ratio of methanol to triglyceride } \\
\text { simpler equipment setup and the separation and } \\
\text { purification process } \\
\text { more economical process } \\
\text { low amount of catalyst (enzyme) used } \\
\text { high quality of glycerol product }\end{array}$ & $\begin{array}{l}\text { the large amount of catalyst used in the process gives a } \\
\text { big environmental impact } \\
\text { the large number of catalysts tends to produce a soap, } \\
\text { an unwanted product, and part of the catalyst is } \\
\text { remained in the biodiesel leads to higher } \mathrm{pH} \text {. } \\
\text { produces large amounts of waste water that must be } \\
\text { addressed, so that it is not effective and increases cost } \\
\text { of purification thereby reducing the eligibility of } \\
\text { process } \\
\text { slightly higher reaction temperature } \\
\text { higher catalyst loading compared to conventional } \\
\text { processes }\end{array}$ & $\begin{array}{c}{[4,50,60,} \\
61,104]\end{array}$ \\
\hline Microwave & $\begin{array}{l}\text { reduced reaction time } \\
\text { lower oil/methanol ratio } \\
\text { less energy consumption } \\
\text { environmentally benign } \\
\text { faster reaction, easier route } \\
\text { less by product } \\
\text { high yields of cleaner product } \\
\text { easier separation process }\end{array}$ & $\begin{array}{l}\text { difficult to the process scale-up from laboratory to } \\
\text { industrial scale } \\
\text { safety issues in the industrial vessel due to uncontrolled } \\
\text { heating, } \\
\text { the penetration depth of microwave radiation into the } \\
\text { material absorbs only a few centimeters }\end{array}$ & $\begin{array}{c}{[4,57,58} \\
110,111 \\
112]\end{array}$ \\
\hline Supercritical & $\begin{array}{l}\text { no catalyst needed } \\
\text { environmentally benign } \\
\text { short reaction time } \\
\text { high reaction rate } \\
\text { not affected by FFA and water content in feedstock } \\
\text { high conversion at relatively short time } \\
\text { free fatty acids and glycerides react at equivalent } \\
\text { rates } \\
\text { homogeneous phase reaction } \\
\text { does not need to be treated impurities in the } \\
\text { feedstock because it does not affect the reaction } \\
\text { strongly }\end{array}$ & $\begin{array}{l}\text { high cost apparatus } \\
\text { high operation temperature }\left(250-400{ }^{\circ} \mathrm{C}\right) \\
\text { high operation pressure }(40-45 \mathrm{MPa}) \text { so that it is not } \\
\text { feasible in the large scale industry } \\
\text { high molar ratio of alcohol to oil (more than } 40: 1)\end{array}$ & $\begin{array}{c}{[50,53,56,} \\
115,119, \\
160]\end{array}$ \\
\hline Enzymatic & $\begin{array}{l}\text { high activity, selectivity, and specific that can help } \\
\text { the complex chemical processes under mild } \\
\text { conditions } \\
\text { environmentally friendly } \\
\text { not affected by high FFA in feedstock because FFA } \\
\text { can be completely converted to methyl esters } \\
\text { reusability of the enzyme catalyst } \\
\text { capable of producing high purity of biodiesel } \\
\text { reusable leads to lower the catalytic process cost }\end{array}$ & $\begin{array}{l}\text { enzyme catalyst can not be operated at too high reactor } \\
\text { temperature because the enzyme will be denatured } \\
\text { utilization of the enzyme catalyst industrially is still } \\
\text { constrained due to high price of the enzyme } \\
\text { low biodiesel yield } \\
\text { slow reaction rate } \\
\text { unstable } \\
\text { need of organic solvents } \\
\text { need of water in the reaction mixture } \\
\text { deactivation of enzyme } \\
\text { require long reaction times and inhibitory effect of } \\
\text { glycerol on the enzymatic activity that makes the } \\
\text { process becomes uneconomical }\end{array}$ & $\begin{array}{c}{[38,48,52,} \\
121,130, \\
161-163]\end{array}$ \\
\hline $\begin{array}{l}\text { Heterogeneous } \\
\text { base catalyst }\end{array}$ & $\begin{array}{l}\text { simple production process and purification steps } \\
\text { low amount of wastewater } \\
\text { simple process equipment and reduced } \\
\text { environmental impact } \\
\text { reusable catalyst } \\
\text { simple catalyst removal } \\
\text { low reaction temperature } \\
\text { short reaction time } \\
\text { cheap process cost } \\
\text { high biodiesel yield } \\
\text { efficient in the use of catalyst }\end{array}$ & $\begin{array}{l}\text { require high energy } \\
\text { difficult recovery glycerol as a by-product } \\
\text { the acidic or alkaline catalyst wastewater } \\
\text { limitation of the high free fatty acid content and } \\
\text { anhydrous starting raw materials } \\
\text { require an additional cost for treatment of the } \\
\text { downstream process }\end{array}$ & $\begin{array}{c}{[45,46,48,} \\
50,121 \\
164,165]\end{array}$ \\
\hline
\end{tabular}


Table 2.... (continued)

\begin{tabular}{|c|c|c|c|}
\hline Method & Advantages & Disadvantages & Ref. \\
\hline $\begin{array}{l}\text { Heterogeneous } \\
\text { acid catalyst }\end{array}$ & $\begin{array}{l}\text { simple biodiesel purification step } \\
\text { allowing a continuous process } \\
\text { insensitive to FFA content } \\
\text { catalyzing esterification and transesterification } \\
\text { simultaneously } \\
\text { removing washing step of product } \\
\text { easy separation of catalyst from the reaction } \\
\text { mixture } \\
\text { easy regeneration and recycling of catalyst } \\
\text { elimination of corrosion problem } \\
\text { high biodiesel yield } \\
\text { low catalyst needed } \\
\text { environmental benign friendly }\end{array}$ & $\begin{array}{l}\text { low catalytic activity } \\
\text { requirement of high reaction temperature }\left(\sim 200^{\circ} \mathrm{C}\right) \\
\text { long reaction time }(8-20 \mathrm{~h}) \\
\text { leaching of active components of the catalyst leads to } \\
\text { requirement of purification step } \\
\text { generates waste solvent that can increase production } \\
\text { cost of biodiesel as well as can reduce activity of the } \\
\text { catalyst }\end{array}$ & $\begin{array}{l}{[38,46,50,} \\
134,136 \\
144-149 \\
166,167]\end{array}$ \\
\hline $\begin{array}{l}\text { Homogeneous } \\
\text { base catalyst }\end{array}$ & $\begin{array}{l}\text { short reaction time (between } 10 \text { minutes to } 2 \text { hours) } \\
\text { mild reaction temperatures }\left(25-70^{\circ} \mathrm{C}\right) \text { and } \\
\text { atmospheric pressure } \\
\text { produce high yield of biodiesel (more than } 97 \%) \\
\text { high conversion in a short reaction time } \\
\text { widely available and inexpensive } \\
\text { better yield than acidic } \\
\text { the reaction is faster compared with the acid } \\
\text { catalysis } \\
\text { rate for the base-catalyzed reaction would be } 4000 \\
\text { times faster compared to the acidic catalyst }\end{array}$ & $\begin{array}{l}\text { high energy consumption } \\
\text { very sensitive to the purity of the reactans } \\
\text { no water content in all starting materials } \\
\text { only suitable for pure vegetable oil feeds without } \\
\text { extensive pre-tretament }\end{array}$ & $\begin{array}{c}{[31,38,39,4} \\
3,46,48 \\
107]\end{array}$ \\
\hline $\begin{array}{l}\text { Homogeneous } \\
\text { acid catalyst }\end{array}$ & $\begin{array}{l}\text { can catalyze esterification and transesterification } \\
\text { simultaneously } \\
\text { not sensitive to the FFA content in the feedstock } \\
\text { more economical than the base-catalyzed process }\end{array}$ & $\begin{array}{l}\text { presence of water in the feedstock would affect the } \\
\text { transesterification reaction } \\
\text { long reaction time } \\
\text { slow reaction rate } \\
\text { high reaction temperature } \\
\text { high molar ratio of alcohol to oil } \\
\text { difficult in the catalyst separation } \\
\text { problems of environmental and corrosion } \\
\text { requirement of waste water system } \\
\text { slower } 4000 \text { times than the alkali-catalyzed system }\end{array}$ & $\begin{array}{l}{[4,26,38} \\
35,39 \\
134,150 \\
159]\end{array}$ \\
\hline
\end{tabular}




\subsection{Heterogeneous acid catalysis}

Previous researchers focused on heterogeneous acid catalysts indicate that the solid acid catalysts have potential instead of liquid acid catalysts [134]. The heterogeneous acid catalysts have great potential to be applied in the commercial biodiesel industries due to simpler biodiesel purification step, allowing a continuous process, and capable of handling lowquality feedstock with high FFA level through esterification and transesterification simultaneously [46].

The heterogeneous acid catalysts, such as ion exchange resins (amberlyst, nafion silica, etc.), tungsten $\left(\mathrm{WO}_{3} / \mathrm{ZrO}_{2}\right)$, sulfated catalyst $\left(\mathrm{SO}_{4}^{2-} / \mathrm{ZrO}_{2}, \mathrm{SO}_{4}{ }^{2} / / \mathrm{TiO}_{2}\right)$, hetero polyacid, $\mathrm{Fe}-\mathrm{Zn}$ DMC (double metal cyanide catalysts), zinc stearate $\left(\mathrm{Zn}\left(\mathrm{C}_{18} \mathrm{H}_{35} \mathrm{O}_{2}\right)_{2}\right)$, zirconium oxide $(\mathrm{ZrO} 2)$, titanium oxide $\left(\mathrm{TiO}_{2}\right)$, tin oxide $\left(\mathrm{SnO}_{2}\right)$, zeolites, sulfonic ion-exchange resin, sulfonic modified mesostructured silica, and sulfonated carbon-based catalyst, are usually used in the esterification or transesterification [39,43,46, 140,135-143]. Concerning the reaction mechanism of heterogeneous acid catalysis for transesterification, FFA reacts with methanol to form methyl ester. Firstly, FFA is adsorbed on the solid surface acid sites, while the FFA interacts with acidic sites resulting in carbocation mechanism. In the second step, methanol attacks to form a tetrahedral intermediate. Finally, the water molecule is eliminated from the tetrahedral intermediates to form methyl ester. In the transesterification, acylglycerol, including tri-, di-, and monoglycerides, reacts with methanol to form methyl ester [46].

The advantages and disadvantages of the heterogeneous acid catalysts in transesterification process are shown in Table 2 . In this process, the catalyst reusability or possibility of catalyst deactivation was investigated. The catalyst reusability has been studied and optimized to reduce the cost of the process [46,134,136,144-149]. The efficiency of the catalyst depends on its reusability in which the catalyst can be reused several times with slightly lesser activity. In the solid acidcatalyzed transesterification reaction, the unique characteristics may be existed, such as the interconnected system of large pores, the moderate to high concentration of strong acid sites, and a hydrophobic surface of the catalyst $[38,39,137,142,143,146,149]$. Also, the heterogeneous acid catalysts are more useful in industrial scale than the homogeneous acid catalysts due to containing various acid sites with different strengths of Brönsted or Lewis acidity [150].

Moreover, development of continuous flow reactor system using the heterogeneous catalyst system was also studied before which focused on the reactor studies [39,41,78-81, 131,135,151-153]. Darnoko and Cheryan [77] used continuous stirred tank reactor (CSTR) for biodiesel production by transesterification of palm oil. The most researchers developed fixed bed tubular continuous flow reactor to produce biodiesel [41,78-81,131,135,151,152]. Advantages of using continuous flow process are a lower cost of the separation and purification steps, shorter processing time, and comparable to commercial petroleum-based diesel fuel [140].

\subsection{Homogeneous base catalysis}

Transesterification reaction using the homogeneous alkaline catalyst is the most common used in the laboratory and industrial scale [154]. Due to in a relatively short reaction time and mild reaction temperatures, it can produce a high yield of biodiesel [46]. Besides, the homogeneous base transesterification has a better yield than acidic, because the reaction is faster (only 30 minutes compared to 1-8 $\mathrm{h}$ for the acid catalysis) with the same level of biodiesel yield (above 90\% for both) [36]. The rate for the base-catalyzed reaction would be 4000 times faster compared to the acidic catalyst [38,48]. The most common homogeneous base catalysts are sodium hydroxide $(\mathrm{NaOH})$ or potassium hydroxide $(\mathrm{KOH}) \quad[36,38]$, and alkoxide, such as potassium dan sodium methoxide $\left(\mathrm{NaOCH}_{3}\right.$, $\left.\mathrm{KOCH}_{3}\right)$ [155]. The catalysts can effectively produce an intermediate of methoxide that will react with vegetable oil to produce biodiesel and glycerol [52]. Reaction mechanism of the base-catalyzed transesterification of vegetable oils involved three steps, including the production of alkoxide ion and protonated catalyst, the formation a tetrahedral intermediate, and deprotonation catalyst. Detail of this mechanism can be found in some references [156,157].

However, the homogeneous basic transesterification has some limitations. This process takes high energy consumption leading to increased cost of capital equipment as well as safety issues [50]. The base-catalyzed reaction is very sensitive to the purity of the reactants. The content of free fatty acids should not exceed 0.5 wt.\% [35], or acid value should be less than $1 \mathrm{mg} \mathrm{KOH/g}[31,36]$. All 
starting materials also no water content [46]. High FFA content in oil or fat causes a reaction with alkali catalyst to form soap, which is highly undesirable. The soap formed in reaction by-products can reduce the yield of fatty acid methyl ester (FAME) drastically and prevents the glycerol separation also inhibit biodiesel purification process, including water washing treatment [37,38]. If the FFA content in the oil were about $3 \%$, the alkaline-catalyzed transesterification process is not suitable to produce esters from unrefined oils [28,39]. The limitations make alkali-catalyzed transesterification only suitable for pure vegetable oil feeds without extensive pre-treatment [31]. The presence of water in starting materials affects the saponification process, reducing the activity of the catalyst, increases the reaction mixture viscosity and causes the stable emulsion formation, and inhibits the glycerol produced separation. Besides, water can promote ester hydrolysis to form FFA leading to reaction with alkali to form soap lowering the esters yield [31,43,46,107].

\subsection{Homogeneous acid catalysis}

Due to limitations on homogeneous basecatalyzed transesterification especially for the high FFAs content of oil or fat, acid catalysts were proposed to overcome the limitations. The homogeneous acid catalyst can be used to catalyze both esterification and transesterification. Therefore, the saponification reaction can be prevented due to the conversion of the FFA directly into ester by esterification, while glycerides are converted into ester via transesterification $[46,158]$. The most common catalysts for acid-catalyzed transesterification are sulfuric acid $\left(\mathrm{H}_{2} \mathrm{SO}_{4}\right)$, hydrochloric acid $(\mathrm{HCl})$ [43], sulfonic acid and phosphoric acid $\left(\mathrm{H}_{3} \mathrm{PO}_{4}\right)$ [150]. The sulfuric acid $\left(\mathrm{H}_{2} \mathrm{SO}_{4}\right)$ is most widely used because it has good catalytic activity and can be added directly to methanol. In general, $1-2 \% \mathrm{H}_{2} \mathrm{SO}_{4}$ concentration was used in the esterification [46]. Concerning the possible reaction mechanism in the acid catalysis system, three steps of mechanism has been found in works of literature [25,46,157]. The first step is protonation of a carbonyl group in the glyceride molecule by the acid catalyst. The second step is the formation of tetrahedral intermediate, while the third step is a migration of proton and breakdown of the intermediate to form an ester.

The acid catalysts can be used for biodiesel production directly from low-cost feedstocks that commonly have high FFA, such as waste cooking oil and greases $[4,38,39]$. The acid catalysis is more efficient when the amount of FFA in the oil exceeds 1 wt.\% [26,31,159]. However, the presence of water in the feedstock would affect the transesterification reaction when using a homogeneous acid catalyst. The water causes ester saponification under alkaline conditions [150]. The FFA and water interfere the primary reaction due to producing undesirable side reactions [41,48,154]. Advantages and disadvantages of using the homogeneous acid catalysts are shown in Table 2.

\section{Prospectives of Plasma Reactors Technology for Biodiesel Production}

The homogeneous transesterification method showed the highest biodiesel yield rather than the heterogeneous method. However, the homogeneous one still has several drawbacks, such as high energy consumption, a high cost of catalyst separation from the reaction mixture, generating a large amount of wastewater during separation, difficulty in recovery of glycerol due to solubility in methanol and catalyst, and forming unwanted soap as a by-product. Consequently, homogeneous transesterification process becomes unattractive in terms of economic consideration. The application of heterogeneous (solid) catalysts in the biodiesel production overcomes the homogeneous catalysis problems. This may due to easy separation of the solid catalysts from reaction products, can avoid unwanted saponification reaction which allows the transesterification of vegetable oils or animal fats with high contents of FFA, can be recovered and reused easily several times with better separation of the final product so that minimizing material and processing cost. The heterogeneous process is environmentally friendly and could be applied in either batch or continuous mode without the need for further purification steps.

Some of the advanced technology are microwave and ultrasound assisted transesterification showing better results on improving the drawbacks in heterogeneous and homogeneous catalysis although there is still some disadvantages. Interestingly another advanced method, plasma reactor technology is potential for the transesterification reaction with or without catalysts [168]. Very shorter reaction time, no soap and no glycerol formations are the advantages of this process. In the plasma electro-catalysis system (non- 
catalytic plasma), several problems should be solved, including difficulty in controlling the reaction mechanism during the plasma process, difficulty in controlling the covalent bond would be excited or ionized, and difficulty in avoiding continuing reactions due to action of high energetic electrons. Future works on the development of the plasma reactor technology for biodiesel production will be focused on controlling the reaction selectivity and mechanism, avoiding continuing reactions due to the action of high energetic electrons, and development of hybrid catalytic-plasma technology for biodiesel production. In the hybrid catalytic-plasma reactor system [168], it should make sure roles of whether the catalyst assists the plasma process or the plasma process supports the catalysis. The significant developments, such as: increasing the reaction surface area, maintaining and probably increasing the non-equilibrium properties of gas discharge, acting as a dielectric-barrier material, and improving the selectivity and efficiency of plasma processes by surface reactions, are also focused. A synergistic role of plasma and catalysis roles is important leading to improved reactant conversions and higher selectivity to the desired products.

\section{Acknowledgement}

The authors would like to express their sincere gratitudes to the Ministry of Research, Technology and Higher Education, Republic of Indonesia for the financial support received under the research project of Hibah Kompetensi Year 2015-2017.

\section{References}

[1] Ma, F., Hanna, M.A. (1999). Biodiesel production: a review. Bioresour. Technol., 70: 1-15.

[2] Boehman, A.L. (2005). Biodiesel production and processing. Fuel Process. Technol., 86(10): 1057-1058.

[3] Knothe, G., Sharp, C.A., Ryan, T.W. (2006). Exhaust emissions of biodiesel, petrodiesel, neat methyl esters, and alkanes in a new technology engine. Energy \& Fuels, 20(1): 403-408.

[4] Vyas, A.P., Verma, J.L., Subrahmanyam, N. (2010). A review on FAME production processes. Fuel, 89(1): 1-9.

[5] Barnard, T.M., Leadbeater, N.E., Boucher, M.B., Stencel, L.M., Wilhite, B.A. (2007). Continuous-flow preparation of biodiesel using microwave heating. Energy \& Fuels, 21(11): 1777-1781.
[6] Barnwal, B.K., Sharma, M.P. (2005). Prospects of biodiesel production from vegetable oils in India. Renew. Sustain. Energy Rev., 9(4): 363-378.

[7] Dmytryshyn, S.L., Dalai, A.K., Chaudhari, S.T., Mishra, H.K., Reaney, M.J. (2004). Synthesis and characterization of vegetable oil derived esters: Evaluation for their diesel additive properties. Bioresour. Technol., 92(1): 55-64.

[8] Demirbas, A. (2002). Biodiesel from vegetable oils via transesterification in supercritical methanol. Energy Convers. Manag., 43(17): 2349-2356.

[9] Bozbas, K. (2008). Biodiesel as an alternative motor fuel: Production and policies in the European Union. Renew. Sustain. Energy Rev., 12(2): 542-552.

[10] Carmen, S., Vinatoru, M., Nishimura, R., Maeda, Y. (2005). Fatty acids methyl esters from vegetable oil by means of ultrasonic energy. Ultrason. Sonochem., 12: 367-372.

[11] Zhang, L., Sheng, B., Xin, Z., Liu, Q., Sun, S. (2010). Kinetics of transesterification of palm oil and dimethyl carbonate for biodiesel production at the catalysis of heterogeneous base catalyst. Bioresour. Technol., 101(21): 81448150 .

[12] Cho, Y.B., Seo, G. (2010). High activity of acid-treated quail eggshell catalysts in the transesterification of palm oil with methanol. Bioresour. Technol., 101(22): 8515-8519.

[13] Khemthong, P., Luadthong, C., Nualpaeng, W., Changsuwan, P., Tongprem, P., Viriyaempikul, N., Faungnawakij, K. (2012). Industrial eggshell wastes as the heterogeneous catalysts for microwave-assisted biodiesel production. Catal. Today, 190(1): 112-116.

[14] Suryaputra, W., Winata, I., Indraswati, N., Ismadji, S. (2013). Waste capiz (Amusium cristatum) shell as a new heterogeneous catalyst for biodiesel production. Renew. Energy, 50: 795-799.

[15] Chakraborty, R., Bepari, S., Banerjee, A. (2010). Transesterification of soybean oil catalyzed by fly ash and egg shell derived solid catalysts. Chem. Eng. J., 165(3): 798805.

[16] Nakatani, N., Takamori, H., Takeda, K., Sakugawa, H. (2009). Transesterification of soybean oil using combusted oyster shell waste as a catalyst. Bioresour. Technol., 100(3): 1510-1513

[17] Wei, Z., Xu, C., Li, B. (2009). Application of waste eggshell as low-cost solid catalyst for biodiesel production. Bioresour. Technol., 100(11): 2883-2885. 
[18] Jazie, A.A., Pramanik, H., Sinha, A.S. (2013). Egg shell as eco-friendly catalyst for transesterification of rapeseed oil : optimization for biodiesel production. Int. J. Sustain. Dev. Green Econ., 2: 27-32.

[19] Berchmans, H.J., Hirata, S. (2008). Biodiesel production from crude Jatropha curcas L. seed oil with a high content of free fatty acids. Bioresour. Technol., 99(6): 1716-1721

[20] Tiwari, A.K., Kumar, A., Raheman, H. (2007). Biodiesel production from jatropha oil (Jatropha curcas) with high free fatty acids: An optimized process. Biomass and Bioenergy, 31: 569-575.

[21] Correia, L.M., Saboya, R.M.A., Campelo, N.D.S., Cecilia, J.A., Rodríguez-Castellón, E., Cavalcante, C.L., Vieira, R.S. (2014). Characterization of calcium oxide catalysts from natural sources and their application in the transesterification of sunflower oil. Bioresour. Technol., 151: 207-213

[22] Ilgen, O. (2011). Dolomite as a heterogeneous catalyst for transesterification of canola oil. Fuel Process. Technol., 92(3): 452-455.

[23] Boey, P.L., Ganesan, S., Maniam, G.P., Khairuddean, M. (2012). Catalysts derived from waste sources in the production of biodiesel using waste cooking oil. Catal. Today, 190(1): 117-121.

[24] Niju, S., Meera, K.M., Begum, S., Anantharaman, N. (2014). Modification of egg shell and its application in biodiesel production. $J$. Saudi Chem. Soc., 18: 702-706.

[25] Meher, L., Sagar, V.D., Naik, S. (2006). Technical aspects of biodiesel production by transesterification-a review. Renew. Sustain. Energy Rev., 10(3): 248-268.

[26] Canakci, M., Gerpen, J.Van. (1999). Biodiesel production via acid catalysis. Trans. ASAE (American Soc. Agric. Eng.), 42(5): 1203-1210.

[27] Freedman, B., Butterfield, R.O., Pryde, E.H. (1986). Transesterification kinetics of soybean oil. J. Am. Oil Chem. Soc., 63(10): 1375-1380.

[28] Ramadhas, A.S., Jayaraj, S., Muraleedharan, C. (2005). Biodiesel production from high FFA rubber seed oil. Fuel, 84(4): 335-340.

[29] Zheng, S., Kates, M., Dubé, M.A., McLean, D.D. (2006). Acid-catalyzed production of biodiesel from waste frying oil. Biomass and Bioenergy, 30(3): 267-272.

[30] Bhatti, H., Hanif, M., Qasim, M. (2008). Biodiesel production from waste tallow. Fuel, 87(13-14): 2961-2966.

[31] Freedman, B., Pryde, E.H., Mounts, T.L. (1984). Variables affecting the yields of fatty esters from transesterified vegetable oils. $J$. Am. Oil Chem. Soc., 61(10): 1638-1643.
[32] Leung, D.Y.C., Guo, Y. (2006). Transesterification of neat and used frying oil: Optimization for biodiesel production. Fuel Process. Technol., 87(10): 883-890.

[33] Issariyakul, T., Dalai, A.K. (2010). Biodiesel production from greenseed canola oil. Energy \& Fuels, 24(7): 4652-4658.

[34] Moser, B.R., Vaughn, S.F. (2010). Coriander seed oil methyl esters as biodiesel fuel: Unique fatty acid composition and excellent oxidative stability. Biomass and Bioenergy, 34(4): 550-558.

[35] Wang, Y., Ou, S., Liu, P., Xue, F., Tang, S. (2006). Comparison of two different processes to synthesize biodiesel by waste cooking oil. J. Mol. Catal. A Chem., 252(1-2): 107-112.

[36] Felizardo, P., Correia, M.J.N., Raposo, I., Mendes, J.F., Berkemeier, R., Bordado, J.M. (2006). Production of biodiesel from waste frying oils. Waste Manag., 26(5): 487-494.

[37] Yan, S., Salley, S.O., Simon, Ng. K.Y. (2009). Simultaneous transesterification and esterification of unrefined or waste oils over $\mathrm{ZnO}$ $\mathrm{La}_{2} \mathrm{O}_{3}$ catalysts. Appl. Catal. A Gen., 353(2): 203-212.

[38] Kulkarni, M.G., Dalai, A.K. (2006). Waste cooking oil's an economical source for biodiesel: A review. Ind. Eng. Chem. Res., 45(9): 2901-2913.

[39] Lotero, E., Liu, Y., Lopez, D.E., Suwannakarn, K., Bruce, D.A., Goodwin, J.G. (2005). Synthesis of biodiesel via acid catalysis. Ind. Eng. Chem. Res., 44(14): 5353-5363.

[40] Yan, S., Di Maggio, C., Mohan, S., Kim, M., Salley, S.O., Ng, K.Y.S. (2010). Advancements in heterogeneous catalysis for biodiesel synthesis. Top Catal., 53(11-12): 721-736.

[41] Maçaira, J., Santana, A., Recasens, F., Larrayoz, M.A. (2011). Biodiesel production using supercritical methanol/carbon dioxide mixtures in a continuous reactor. Fuel, 90(6): 2280-2288.

[42] Zhang, S., Zu, Y.G., Fu, Y.J., Luo, M., Zhang, D.Y., Efferth, T. (2010). Rapid microwaveassisted transesterification of yellow horn oil to biodiesel using a heteropolyacid solid catalyst. Bioresour. Technol., 101(3): 931-936.

[43] Lam, M.K., Lee, K.T., Mohamed, A.R. (2010). Homogeneous, heterogeneous and enzymatic catalysis for transesterification of high free fatty acid oil (waste cooking oil) to biodiesel: a review. Biotechnol. Adv., 28(4): 500-518.

[44] Di Serio, M., Ledda, M., Cozzolino, M., Minutillo, G., Tesser, R., Santacesaria, E. (2006). Transesterification of soybean oil to biodiesel by using heterogeneous basic catalysts. Ind. Eng. Chem. Res., 45(9): 3009-3014. 
[45] Zhang, J., Chen, S., Yang, R., Yan, Y. (2010). Biodiesel production from vegetable oil using heterogenous acid and alkali catalyst. Fuel, 89(10): 2939-2344.

[46] Issariyakul, T., Dalai, A.K. (2014). Biodiesel from vegetable oils. Renew. Sustain. Energy Rev., 31: 446-471.

[47] Ranganathan, S.V., Narasimhan, S.L., Muthukumar, K. (2008). An overview of enzymatic production of biodiesel. Bioresour. Technol., 99(10): 3975-3981.

[48] Fukuda, H., Kond, A., Noda, H. (2001). Biodiesel fuel production by transesterification of oils: A review. J. Biosci. Bioeng., 92(5): 405416.

[49] Boey, P-L., Maniam, G.P., Hamid, S.A. (2011). Performance of calcium oxide as a heterogeneous catalyst in biodiesel production: A review. Chemical Engineering Journal, 168(1): 15-22

[50] Talebian-Kiakalaieh, A., Amin, N.A.S., Mazaheri, H. (2013). A review on novel processes of biodiesel production from waste cooking oil. Appl. Energy, 104: 683-710.

[51] D'Ippolito, S.A., Yori, J.C., Iturria, M.E., Pieck, C.L., Vera, C.R. (2007). Analysis of a two-step, noncatalytic, supercritical biodiesel production process with heat recovery. Energy \& Fuels, 21(4): 339-346.

[52] Tan, K.T., Lee, K.T. (2011). A review on supercritical fluids (SCF) technology in sustainable biodiesel production : Potential and challenges. Renew. Sustain. Energy Rev., 15(5): 2452-2456.

[53] Kusdiana, D., Saka, S. (2004). Two-step preparation for catalyst-free biodiesel fuel production: hydrolysis and methyl esterification. Appl. Biochem. Biotechnol., 113-116: 781-791.

[54] Han, H., Cao, W., Zhang, J. (2005). Preparation of biodiesel from soybean oil using supercritical methanol and $\mathrm{CO}_{2}$ as co-solvent. Process. Biochem., 40(9): 3148-3151.

[55] Demirbas, A. (2007). Biodiesel from sunflower oil in supercritical methanol with calcium oxide. Energy Convers. Manag., 48(3): 937-941.

[56] Yin, J-Z., Xiao, M., Song, J-B. (2008). Biodiesel from soybean oil in supercritical methanol with co-solvent. Energy Convers. Manag., 49(5): 908-912.

[57] Lidström, P., Tierney, J., Wathey, B., Westman, J. (2001). Microwave assisted organic synthesis - a review. Tetrahedron, 57(589): 9225-9283.

[58] Azcan, N., Danisman, A. (2007). Alkali catalyzed transesterification of cottonseed oil by microwave irradiation. Fuel, 86(17-18): 26392644.
[59] Singh, A.K., Fernando, S.D., Hernandez, R. (2007). Base-catalyzed fast transesterification of soybean oil using ultrasonication. Energy \& Fuels, 32(8): 1161-1164.

[60] Ji, J., Wang, J., Li, Y., Yu, Y., Xu, Z. (2006). Preparation of biodiesel with the help of ultrasonic and hydrodynamic cavitation. Ultrasonics, 44: 411-414.

[61] Siatis, N.G., Kimbaris, A.C., Pappas, C.S., Tarantilis, P.A., Polissiou, M.G. (2006). Improvement of biodiesel production based on the application of ultrasound: Monitoring of the procedure by FTIR spectroscopy. J. Am. Oil Chem. Soc., 83(1): 53-57.

[62] Kalva, A., Sivasankar, T., Moholkar, V.S. (2009). Physical mechanism of ultrasoundassisted synthesis of biodiesel. Ind. Eng. Chem. Res., 48(1): 534-544.

[63] Verziu, M., Florea, M., Simon, S., Simon, V., Filip, P., Parvulescu, V.I., Hardacre, C. (2009). Transesterification of vegetable oils on basic large mesoporous alumina supported alkaline fluorides-Evidences of the nature of the active site and catalytic performances. $J$. Catal., 263(1): 56-66.

[64] Lawson, J.A., Baosman, A.A. (2005). Chemical synthesis methods using electro-catalysis. US Patent 2005/0262760 A1 (1 Dec. 2005).

[65] Lawson, J.A., Baosman, A.A.. (2010). Method of electro-catalytic reaction to produce mono alkyl esters for renewable biodiesel. US Patent 7,722,755 B2 (25 May 2010).

[66] Istadi, I., Yudhistira, A.D., Anggoro, D.D., Buchori, L. (2014). Electro-catalysis system for biodiesel synthesis from palm oil over dielectric-barrier discharge plasma reactor. Bull. Chem. React. Eng. Catal., 9(2): 111-120.

[67] Salamatinia, B., Mootabadi, H., Bhatia, S., Abdullah, A.Z. (2010). Optimization of ultrasonic-assisted heterogeneous biodiesel production from palm oil: A response surface methodology approach. Fuel Process. Technol., 91(5): 441-448.

[68] Carmen, S., Vinatoru, M., Maeda, Y., Bandow, H. (2007). Ultrasonically driven continuous process for vegetable oil transesterification. Ultrason. Sonochem., 14(4): 413-417.

[69] Colucci, J.A., Borrero, E.E., Alape, F. (2005). Biodiesel from an alkaline transesterification reaction of soybean oil using ultrasonic mixing. J. Am. Oil Chem. Soc., 82(7): 525-530.

[70] Parkar, P.A., Choudhary, H.A., Moholkar, V.S. (2012). Mechanistic and kinetic investigations in ultrasound assisted acid catalyzed biodiesel synthesis. Chem. Eng. J., 187: 248260. 
[71] Chen, K.S., Lin, Y.C., Hsu, K.H., Wang, H.K. (2012). Improving biodiesel yields from waste cooking oil by using sodium methoxide and a microwave heating system. Energy, 38(1): 151-156.

[72] Lertsathapornsuk, V., Pairintra, R., Aryusuk, K., Krisnangkura, K. (2008). Microwave assisted in continuous biodiesel production from waste frying palm oil and its performance in a $100 \mathrm{~kW}$ diesel generator. Fuel Process. Technol., 89(12): 1330-1336.

[73] Encinar, J.M,, González, J.F., Martínez, G., Sánchez, N., Pardal, A. (2012). Soybean oil transesterification by the use of a microwave flow system. Fuel, 95: 386-393.

[74] Mazubert, A., Taylor, C., Aubin, J., Poux, M. (2014). Key role of temperature monitoring in interpretation of microwave effect on transesterification and esterification reactions for biodiesel production. Bioresour. Technol., 161: 270-279.

[75] Ma, F., Clements, L.D., Hanna, M.A. (1998). The effects of catalyst, free fatty acids, and water on transesterification of beef tallow. Trans. ASAE (American Soc Agric Eng.), 41(5): 1261-1264.

[76] Endalew, A.K., Kiros, Y., Zanzi, R. (2011). Heterogeneous catalysis for biodiesel production from Jatropha curcas oil (JCO). Energy, 36(5): 2693-2700.

[77] Darnoko, D., Cheryan, M. (2000). Continuous production of palm methyl esters. J. Am. Oil Chem. Soc., 77(12): 1269-1272.

[78] Hsieh, L.S., Kumar, U., Wu, J.C.S. (2010). Continuous production of biodiesel in a packed-bed reactor using shell-core structural $\mathrm{Ca}\left(\mathrm{C}_{3} \mathrm{H}_{7} \mathrm{O}_{3}\right)_{2} / \mathrm{CaCO}_{3}$ catalyst. Chem. Eng. J., 158(2): 250-256.

[79] Feng, Y., Zhang, A., Li, J., He, B. (2011). A continuous process for biodiesel production in a fixed bed reactor packed with cationexchange resin as heterogeneous catalyst. Bioresour. Technol., 102(3): 3607-3609.

[80] Ren, Y., He, B., Yan, F., Wang, H., Cheng, Y., Lin, L., Feng, Y., Li, J. (2012). Continuous biodiesel production in a fixed bed reactor packed with anion-exchange resin as heterogeneous catalyst. Bioresour. Technol., 113: 1922 .

[81] Da Silva, F.M., Pinho, D.M.M., Houg, G.P., Reis, I.B.A., Kawamura, M., Quemel, M.S.R., Montes, P.R., Suarez, P.A.Z. (2014). Continuous biodiesel production using a fixed-bed Lewis-based catalytic system. Chem. Eng. Res. Des., 92(8): 1463-1469.

[82] Yin, J-Z., Xiao, M., Wang, A-Q., Xiu, Z-L. (2008). Synthesis of biodiesel from soybean oil by coupling catalysis with subcritical metha- nol. Energy Convers. Manag., 49(12): 35123516 .

[83] Micic, R.D., Tomić, M.D., Kiss, F.E., NikolićDjorić, E.B., Simikić, M. (2014). Influence of reaction conditions and type of alcohol on biodiesel yields and process economics of supercritical transesterification. Energy Convers. Manag., 86: 717-726.

[84] Jahanmiri, A,, Rahimpour, M,R, Mohamadzadeh Shirazi, M., Hooshmand, N., Taghvaei, H. (2012). Naphtha cracking through a pulsed DBD plasma reactor: Effect of applied voltage, pulse repetition frequency and electrode material. Chem. Eng. J., 191: 416-425.

[85] Rahimpour, M.R,, Jahanmiri, A., Mohamadzadeh Shirazi, M., Hooshmand, N., Taghvaei, H. (2013). Combination of non-thermal plasma and heterogeneous catalysis for methane and hexadecane co-cracking: Effect of voltage and catalyst configuration. Chem. Eng. J., 219: 245-253.

[86] Huang, A., Xia, G., Wang, J., Suib, S.L., Hayashi, Y., Matsumoto, H. (2000). $\mathrm{CO}_{2}$ reforming of $\mathrm{CH}_{4}$ by atmospheric pressure $\mathrm{AC}$ discharge plasmas. J. Catal., 189(2): 349-359.

[87] Li, M., Xu, G., Tian, Y., Chen, L., Fu, H. (2004). Carbon dioxide reforming of methane using DC corona discharge plasma reaction. J. Phys. Chem. A., 108(10): 1687-1693.

[88] Pietruszka, B., Heintze, M. (2004). Methane conversion at low temperature: the combined application of catalysis and non-equilibrium plasma. Catal. Today, 90(1-2): 151-158

[89] Zhang, K., Eliasson, B., Kogelschatz, U. (2002). Direct conversion of greenhouse gases to synthesis gas and $\mathrm{C}_{4}$ hydrocarbons over zeolite hy promoted by a dielectric-barrier discharge. Ind. Eng. Chem. Res., 41(6): 14621468 .

[90] Zou, J., Zhang, Y., Liu, C., Li, Y., Eliasson, B. (2003). Starch-enhanced synthesis of oxygenates from methane and carbon dioxide using dielectric-barrier discharges. Plasma Chem. Plasma Process., 23(1): 69-82.

[91] Caldwell, T.A., Le, H., Lobban, L.L., Mallinson, R.G. (2001). Partial oxidation of methane to form synthesis gas in a tubular AC plasma reactor. In: Spivey, J.J., Iglesia, E., and Fleisch TH, editor. Studies in Surface Science and Catalysis. Elsevier Science B.V. p. 265-270.

[92] Liu, C., Marafee, A., Mallinson, R., Lobban, L. (1997). Methane conversion to higher hydrocarbons in a corona discharge over metal oxide catalysts with $\mathrm{OH}$ groups. Appl. Catal. A Gen., 164(1-2): 21-33.

[93] Larkin, D.W., Zhou, L., Lobban, L.L., Mallinson R.G. (2001). Product selectivity control 
and organic oxygenate pathways from partial oxidation of methane in a silent electric discharge reactor. Ind. Eng. Chem. Res., 40(23): 5496-5506.

[94] Istadi, I., Amin, N.A.S. (2006). Co-generation of synthesis gas and $\mathrm{C}_{2+}$ hydrocarbons from methane and carbon dioxide in a hybrid catalytic-plasma reactor: A review. Fuel, 85(5-6): 577-592.

[95] Istadi, I., Amin, N.A.S. (2006). Hybrid artificial neural network-genetic algorithm technique for modeling and optimization of plasma reactor. Ind. Eng. Chem. Res., 45(20): 6655-6664.

[96] Kogelschatz, U. (2003). Dielectric-barrier discharges : their history, discharge physics, and industrial applications. plasma chem plasma process. Plasma Chemistry and Plasma Processing, 23(1): 1-46.

[97] Istadi, I. (2006). Catalytic conversion of methane and carbon dioxide in a conventional fixed bed and dielectric-barrier discharge plasma reactors. PhD Thesis. Universiti Teknologi Malaysia, Malaysia.

[98] Fridman, A. (2008). Plasma chemistry. New York, United States of America: Cambridge University Press.

[99] Lee, D.H., Kim, T. (2013). Plasma-catalyst hybrid methanol-steam reforming for hydrogen production. Int. J. Hydrogen Energy, 38(14): 6039-6043.

[100] Kropf, M.M. (2009). Ultrasonic and microwave methods for enhacing the rate of a chemical reaction and apparatus for such methods. US Patent 2009/0000941 A1 (1 Jan. 2009).

[101] Hanh, H.D., Dong, N.T., Okitsu, K., Maeda, Y., Nishimura, R. (2007). Effects of molar ratio, catalyst concentration and temperature on transesterification of triolein with ethanol under ultrasonic irradiation. J. Japan Pet. Inst., 50(4): 195-199.

[102] Vyas, A.P., Verma, J.L, Subrahmanyam, N. (2011). Effects of molar ratio, alkali catalyst concentration and temperature on transesterification of jatropha oil with methanol under ultrasonic irradiation. Adv. Chem. Eng. Sci., 1: 45-50.

[103] Wang, J., Huang, Q., Huang, F., Wang, J., Huang, Q. (2007). Lipase-catalyzed production of biodiesel from high acid value waste oil using ultrasonic assistant. Chin. J. BioTechnol., 23(6): 1121-1128.

[104] Santos, F.F.P., Rodrigues, S., Fernandes, F.A.N. (2009). Optimization of the production of biodiesel from soybean oil by ultrasound assisted methanolysis. Fuel Process. Technol., 90(2): 312-316.
[105] Badday, A.S., Abdullah, A.Z., Lee, K.T., Khayoon, M.S. (2012). Intensification of biodiesel production via ultrasonic-assisted process: A critical review on fundamentals and recent development. Renew. Sustain. Energy Rev., 16(7): 4574-4587.

[106] Ramachandran, K., Suganya, T., Gandhi, N.N., Renganathan, S. (2013). Recent developments for biodiesel production by ultrasonic assist transesterification using different heterogeneous catalyst: A review. Renew. Sustain. Energy Rev., 22: 410-418.

[107] Veljković, V.B., Avramović, J.M., Stamenković, O.S. (2012). Biodiesel production by ultrasound-assisted transesterification: State of the art and the perspectives. Renew. Sustain. Energy Rev., 16: 1193-1209.

[108] Refaat, A.A., Sheltawy, S.T., Sadek, K.U. (2008). Optimum reaction time, performance and exhaust emissions of biodiesel produced by microwave irradiation. Int. J. Environ. Sci. Technol., 5(3): 315-322.

[109] Mutyala, S., Fairbridge, C., Paré, J.R.J., Bélanger, J.M.R., Ng, S., Hawkins, R. (2010). Microwave applications to oil sands and petroleum: A review. Fuel Process. Technol., 91(2): 127-135.

[110] Motasemi, F., Ani, F.N. (2012). A review on microwave-assisted production of biodiesel. Renew. Sustain. Energy Rev., 16(7): 47194733 .

[111] Sajjadi, B., Abdul Aziz, A.R., Ibrahim, S. (2014). Investigation, modelling and reviewing the effective parameters in microwaveassisted transesterification. Renew. Sustain. Energy Rev., 37: 762-777.

[112] Groisman, Y., Gedanken, A. (2008). Continuous flow, circulating microwave system and its application in nanoparticle fabrication and biodiesel synthesis. J. Phys. Chem. C., 112(24): 8802-8808.

[113] Manco, I., Giordani, L., Vaccari, V., Oddone, M. (2012). Microwave technology for the biodiesel production: Analytical assessments. Fuel, 95: 108-112.

[114] He, H., Sun, S., Wang, T., Zhu, S. (2007). Transesterification kinetics of soybean oil for production of biodiesel in supercritical methanol. J. Am. Oil Chem. Soc., 84(4): 399-404.

[115] Kusdiana, D., Saka, S. (2004). Effects of water on biodiesel fuel production by supercritical methanol treatment. Bioresour. Technol., 91(3): 289-295.

[116] Saka, S., Kusdiana, D. (2001). Biodiesel fuel from rapeseed oil as prepared in supercritical methanol. Fuel, 80: 225-231.

[117] Warabi, Y., Kusdiana, D., Saka, S. (2004). Biodiesel fuel from vegetable oil by various 
supercritical alcohols. Appl. Biochem. Biotechnol., 113: 793-801.

[118] Pinnarat, T., Savage, P.E. (2008). Assessment of noncatalytic biodiesel synthesis using supercritical reaction conditions. Ind. Eng. Chem. Res., 47(18): 6801-6808.

[119] Helwani, Z., Othman, M.R., Aziz, N., Fernando, W.J.N., Kim, J. (2009). Technologies for production of biodiesel focusing on green catalytic techniques: A review. Fuel Process. Technol., 90(12): 1502-1514.

[120] Warabi, Y., Kusdiana, D., Saka, S. (2004). Reactivity of triglycerides and fatty acids of rapeseed oil in supercritical alcohols. Bioresour. Technol., 91(3): 283-287.

[121] Bajaj, A., Lohan, P., Jha, P.N., Mehrotra, R. (2010). Biodiesel production through lipase catalyzed transesterification: An overview. J. Mol. Catal. B Enzym, 62(1): 9-14.

[122] Fjerbaek, L., Christensen, K.V., Norddahl, B. (2009). A review of the current state of biodiesel production using enzymatic transesterification. Biotechnol. Bioeng., 102(5): 12981315 .

[123] Miller, C., Austin, H., Posorske, L., Gonzlez, J. (1988). Characteristics of an immobilized lipase for the commercial synthesis of esters. $J$. Am. Oil Chem. Soc., 65(6): 927-931.

[124] Posorske, L.H., LeFebvre, G.K., Miller, C.A., Hansen, T.T., Glenvig, B.L. (1988). Process considerations of continuous fat modification with an immobilized lipase. J. Am. Oil Chem. Soc., 65(6): 922-926.

[125] Paiva, A.L., Balcao, V.M., Malcata, F.X. (2000). Kinetics and mechanisms of reactions catalyzed by immobilized lipases. Enzyme Microb. Technol., 27(3-5): 187-204.

[126] Babu, N.S., Sree, R., Prasad, P.S.S., Lingaiah, N. (2008). Room-temperature transesterification of edible and nonedible oils using a heterogeneous strong basic $\mathrm{Mg} / \mathrm{La}$ catalyst. Energy \& Fuels, 22(3): 1965-1971.

[127] Xie, W., Li, H. (2006). Alumina-supported potassium iodide as a heterogeneous catalyst for biodiesel production from soybean oil. J. Mol. Catal. A Chem., 255(1-2): 1-9.

[128] Garcia, C.M., Teixeira, S., Marciniuk, L.L., Schuchardt, U. (2008). Transesterification of soybean oil catalyzed by sulfated zirconia. Bioresour. Technol., 99(14): 6608-6613.

[129] López, D.E., Goodwin, J.G., Bruce, D.A., Lotero, E. (2014). Transesterification of triacetin with methanol on solid acid and base catalysts. Appl. Catal. A Gen., 295(2): 97-105.

[130] Marchetti, J.M., Miguel, V.U., Errazu, A.F. (2007). Possible methods for biodiesel produc- tion. Renew. Sustain. Energy Rev., 11(6): 1300-1311.

[131] McNeff, C.V., McNeff, L.C., Yan, B., Nowlan, D.T., Rasmussen, M., Gyberg, A.E., Krohn, B.J., Fedie, R.L., Hoye, T.R. (2008). A continuous catalytic system for biodiesel production. Appl. Catal. A Gen., 343(1-2): 39-48.

[132] Islam, A., Taufiq-Yap, Y.H., Chu, C-M., Chan, E-S., Ravindra, P. (2013). Studies on design of heterogeneous catalysts for biodiesel production. Process Saf. Environ. Prot., 91(1-2): 131-144.

[133] Kouzu, M., Kasuno, T., Tajika, M., Sugimoto, Y., Yamanaka, S., Hidaka, J. (2008). Calcium oxide as a solid base catalyst for transesterification of soybean oil and its application to biodiesel production. Fuel, 87(12): 2798-2806.

[134] Jacobson, K., Gopinath, R., Meher, L., Dalai, A. (2008). Solid acid catalyzed biodiesel production from waste cooking oil. Appl. Catal. B Environ., 85(1-2): 86-91.

[135] Furuta, S., Matsuhashi, H., Arata, K. (2006). Biodiesel fuel production with solid amorphous-zirconia catalysis in fixed bed reactor. Biomass and Bioenergy, 30(10): 870-873

[136] Chen, H., Peng, B., Wang, D., Wang, J. (2007). Biodiesel production by the transesterification of cottonseed oil by solid acid catalysts. Front. Chem. Eng. China, 1(1): 1115.

[137] Srinivas, D., Satyarthi, J.K. (2011). Biodiesel production from vegetable oils and animal fat over solid acid double-metal cyanide catalysts. Catal. Surv. Asia, 15(3): 145-160.

[138] Ramu, S., Lingaiah, N., Prabhavathi Devi, B.L.A., Prasad, R.B.N., Suryanarayana, I., Prasad, P.S.S. (2004). Esterification of palmitic acid with methanol over tungsten oxide supported on zirconia solid acid catalysts : effect of method of preparation of the catalyst on its structural stability and reactivity. Appl. Catal. A Gen., 276(1-2): 163-168.

[139] Verhoef, M.J., Kooyman, P.J., Peters, J.A., van Bekkum, H. (1999). A study on the stability of MCM-41-supported heteropoly acids under liquid- and gas-phase esterification conditions. Microporous Mesoporous Mater., 27(23): 365-371.

[140] De Almeida, R.M., Noda, L.K., Gonçalves, N.S., Meneghetti, S.M.P., Meneghetti, M.R. (2008). Transesterification reaction of vegetable oils, using superacid sulfated $\mathrm{TiO}_{2}$-base catalysts. Appl. Catal. A Gen., 347(3): 100105.

[141] Furuta, S., Matsuhashi, H., Arata, K. (2004). Biodiesel fuel production with solid superacid catalysis in fixed bed reactor under atmos- 
pheric pressure. Catal. Commun., 5(12): 721723

[142] Mbaraka, I.K., McGuire, K.J., Shanks, B.H. (2006). Acidic mesoporous silica for the catalytic conversion of fatty acids in beef tallow. Ind. Eng. Chem. Res., 45(9): 3022-3028.

[143] Lou, W.Y., Zong, M.H., Duan, Z.Q. (2008). Efficient production of biodiesel from high free fatty acid-containing waste oils using various carbohydrate-derived solid acid catalysts. Bioresour. Technol., 99(18): 8752-8758.

[144] Chen, G., Fang, B. (2011). Preparation of solid acid catalyst from glucose-starch mixture for biodiesel production. Bioresour. Technol., 102(3): 2635-2640.

[145] Komintarachat, C., Chuepeng, S. (2009). Solid acid catalyst for biodiesel production from waste used cooking oils. Ind. Eng. Chem. Res., 48(20): 9350-9353.

[146] Yan, F., Yuan, Z., Lu, P., Luo, W., Yang, L., Deng, L. (2011). Fe-Zn double-metal cyanide complexes catalyzed biodiesel production from high-acid-value oil. Renew. Energy, 36(7): 2026-2031.

[147] Yan, F., Yuan, Z., Lü, P., Luo, W., Yang, L., Deng, L. (2010). Synthesis of biodiesel by Fe(II)-Zn double-metal cyanide complexes. J. Fuel Chem. Technol., 38(3): 281-286.

[148] Srilatha, K., Issariyakul, T., Lingaiah, N., Sai Prasad, P.S., Kozinski, J., Dalai,A.K. (2010). Efficient esterification and transesterification of used cooking oil using 12 tungstophosphoric acid (TPA)/ $\mathrm{Nb}_{2} \mathrm{O}_{5}$ catalyst. Energy \& Fuels, 24(13), 4748-4755.

[149] Melero, J.A., Bautista, L.F., Morales, G., Iglesias, J., Sánchez-Vázquez, R. (2010). Biodiesel production from crude palm oil using sulfonic acid-modified mesostructured catalysts. Chem. Eng. J., 161(3): 323-331.

[150] Aransiola, E.F., Ojumu, T.V., Oyekola, O.O., Madzimbamuto, T.F., Ikhu-Omoregbe, D.I.O. (2014). A review of current technology for biodiesel production: State of the art. Biomass and Bioenergy, 61: 276-297.

[151] Ketcong, A., Meechan, W., Naree, T., Seneevong, I., Winitsorn, A., Butnark, S., Ngamcharussrivichai, C. (2014). Production of fatty acid methyl esters over a limestone-derived heterogeneous catalyst in a fixed-bed reactor. J. Ind. Eng. Chem., 20(4): 1665-1671.

[152] De Moura, C.V.R., De Castro, A.G., De Moura, E.M., Dos Santos, J.R., Moita Neto, J.M. (2010). Heterogeneous catalysis of babassu oil monitored by thermogravimetric analysis. Energy \& Fuels, 24(15): 6527-6532.

[153] Bunyakiat, K., Makmee, S., Sawangkeaw, R., Ngamprasertsith, S. (2006). Continuous pro- duction of biodiesel via transesterification from vegetable oils in supercritical methanol. Energy \& Fuels, 20(8): 812-817.

[154] Noureddini, H., Gao, X., Philkana, R.S. (2005). Immobilized Pseudomonas cepacia lipase for biodiesel fuel production from soybean oil. Bioresour. Technol., 96(7): 769-777.

[155] Darnoko, D., Cheryan, M. (2000). Kinetics of palm oil transesterification in a batch reactor. J. Am. Oil Chem. Soc., 77(12): 1263-1267.

[156] Demirbas, A. (2005). Biodiesel production from vegetable oils via catalytic and noncatalytic supercritical methanol transesterification methods. Prog. Energy Combust. Sci., 31: 466-487.

[157] Schuchardt, U., Sercheli, R., Matheus, R. (1998). Transesterification of vegetable oils : a review. J. Braz. Chem. Soc., 9(1): 199-210.

[158] Liu, K.S. (1994). Preparation of fatty acid methyl esters for gas-chromatographic analysis of lipids in biological materials. J. Am. Oil Chem. Soc., 71(11): 1179-1187.

[159] Zhang, Y., Dube, M.A., McLean, D.D., Kates, M. (2003). Biodiesel production from waste cooking oil: 1. Process design and technological assessment. Bioresour. Technol., 89(1): 116

[160] Kusdiana, D., Saka, S. (2001). Kinetics of transesterification in rapeseed oil to biodiesel fuel as treated in supercritical methanol. Fuel, 80(5): 693-698.

[161] Shah, S., Sharma, S., Gupta, M.N. (2004). Biodiesel preparation by lipase-catalyzed transesterification of Jatropha oil. Energy \& Fuels, 18(15): 154-159.

[162] Nelson, L.A., Foglia, T.A., Marmer, W.N. (1996). Lipase-catalyzed production of biodiesel. J. Am. Oil Chem. Soc., 73(8): 11911195 .

[163] Kumari, V., Shah, S., Gupta, M.N. (2007). Preparation of biodiesel by lipase-catalyzed transesterification of high free fatty acid containing oil from Madhuca indica. Energy \& Fuels, 21(12): 368-372.

[164] Al-Zuhair, S. (2005). Production of biodiesel by lipase-catalyzed transesterification of vegetable oils: A kinetics study. Biotechnol. Prog., 21(5): 1442-1448.

[165] Du, W., Xu, Y.Y., Liu, D.H., Li, Z.B. (2005). Study on acyl migration in immobilized lipozyme TL-catalyzed transesterification of soybean oil for biodiesel production. J. Mol. Catal. B Enzym., 37(1-6): 68-71.

[166] Suarez, P.A.Z., Meneghetti, S.M.P., Meneghetti, M.R., Wolf, C.R. (2007). Transformation of triglycerides into fuels, polymers 
and chemicals some applications of catalysis in oleochemistry. Quim. Nova., 30(3): 667676.

[167] Jitputti, J., Kitiyanan, B., Rangsunvigit, P., Bunyakiat, K., Attanatho, L., Jenvanitpanjakul, P. (2006). Transesterification of crude palm kernel oil and crude coconut oil by different solid catalysts. Chem. Eng. J., 116(1): 61-66.
[168] Buchori, L., Istadi, I., Purwanto, P., Kurniawan, A., Maulana, T.I. (2016). Preliminary testing of hybrid catalytic-plasma reactor for biodiesel production using modified-carbon catalyst. Bull. Chem. React. Eng. Catal., 11 (1): 59-65. 